\title{
Fusarium casha sp. nov. and F. curculicola sp. nov. in the Fusarium fujikuroi Species Complex Isolated from Amaranthus cruentus and Three Weevil Species in South Africa
}

\author{
Marcele Vermeulen ${ }^{1}$, Lisa A. Rothmann ${ }^{2}$, Wijnand J. Swart ${ }^{2}$ and Marieka Gryzenhout ${ }^{3, *(D)}$ \\ 1 Department of Microbiology \& Biochemistry, University of the Free State, Bloemfontein 9301, South Africa; \\ marcele.vermeulen81@gmail.com \\ 2 Department of Plant Sciences, University of the Free State, Bloemfontein 9301, South Africa; \\ CoetzeeLA@ufs.ac.za (L.A.R.); SwartWJ@ufs.ac.za (W.J.S.) \\ 3 Department of Genetics, University of the Free State, Bloemfontein 9301, South Africa \\ * Correspondence: Gryzenhoutm@ufs.ac.za
}

check for updates

Citation: Vermeulen, M.;

Rothmann, L.A.; Swart, W.J.;

Gryzenhout, M. Fusarium casha sp.

nov. and F. curculicola sp. nov. in the

Fusarium fujikuroi Species Complex Isolated from Amaranthus cruentus and Three Weevil Species in South Africa. Diversity 2021, 13, 472. https://doi.org/10.3390/d13100472

Academic Editor: Stuart Donachie

Received: 16 July 2021

Accepted: 20 August 2021

Published: 28 September 2021

Publisher's Note: MDPI stays neutral with regard to jurisdictional claims in published maps and institutional affiliations.

Copyright: (c) 2021 by the authors. Licensee MDPI, Basel, Switzerland. This article is an open access article distributed under the terms and conditions of the Creative Commons Attribution (CC BY) license (https:/ / creativecommons.org/licenses/by/ $4.0 /)$.

\begin{abstract}
Trials are currently being conducted in South Africa to establish Amaranthus cruentus as a new pseudocereal crop. During recent surveys, Fusarium species were associated with weevil damage in A. cruentus fields. Preliminary studies showed that some of these Fusarium species grouped into two distinct clades within the F. fujikuroi species complex. The aim of this study was to characterize these isolates based on the morphology and phylogeny of the translation elongation factor $1 \alpha(\mathrm{TEF} 1 \alpha)$ gene region, $B$-tubulin 2 (BT) gene region and RNA polymerase II subunit (RPB2), and to determine if these isolates are pathogenic to A. cruentus. Phylogenetic and morphological studies showed that these two clades represent two novel species described here as F. casha and F. curculicola. Both species were shown to have the potential to be pathogenic to A. cruentus during routine greenhouse inoculation tests. While isolations indicate a possible association between these two species and weevils, further research is needed to understand this association and the role of weevils in disease development involving F. casha and F. curculicola in A. cruentus.
\end{abstract}

Keywords: Amaranthus cruentus; Fusarium casha; Fusarium curculicola; phytopathogen; weevils

\section{Introduction}

Food security worldwide currently relies on only a few major crops to feed the growing world population. The introduction of new crops increases crop diversity and, therefore, lowers the exposure to food shortage due to harvest failures. Amaranthus cruentus is one of three Amaranthus species that can be cultivated for grain and has been used as a food source in Central America since 4000 BC [1]. Trials are currently being conducted to establish A. cruentus as a pseudograin crop in South Africa in addition to major crops such as maize and wheat.

In recent years, several new species have been described in the important Fusarium fujikuroi species complex (FFSC) [2-9]. The FFSC includes human and plant pathogens, and several species are known to produce mycotoxins such as beauvericin, fumonisin and moniliformin which can contaminate food sources for human and animal consumption, leading to serious mycotoxicoses [10-12]. Novel species descriptions are important because they increase the knowledge on the diversity, geographic distribution, host range, evolution and global movement of this species complex. Currently, more than 50 phylogenetic clades are known from this complex, with a number of undescribed species still awaiting description $[2,3,5,6,8,9,13]$.

Species belonging to the FFSC group into three distinct clades, namely, the African, American and Asian clades [14-16]. The American clade represents most of the species in the FFSC [3], followed closely by the African clade [4,11,17]. The geographic topology of 
the species complex is thought to reflect the evolutionary origins of the hosts for the various species from these three continental areas, although the pattern is not always followed closely [14]. For example, F. verticillioides belongs to the African clade in the FFSC, but its maize and teosinte (wild Zea spp.) hosts are believed to originate from Mexico or Central America [11,18].

Fusarium species are important pathogens of Amaranthus species [1,19-21]. In South Africa, several Fusarium species have been isolated from Amaranthus hybridus (vegetable amaranth) $[20,21]$. Fusarium oxysporum and F. sambucinum were obtained from root rot symptoms, F. culmorum from cankered stems and F. equiseti, F. oxysporum, F. sambucinum, F. solani, F. subglutinans and F. proliferatum from cankered stems and discolored stem tissues associated with larval galleries of the pigweed weevil (Hypolixus haerens) [20,21]. In Poland, F. avenaceum, F. culmorum and F. oxysporum were found from stem discoloration on A. cruentus [1]. Fusarium culmorum and F. equiseti were also sporadically detected from non-disinfected seeds, and F. culmorum from surface-disinfected seeds [1]. Fusarium equiseti, F. solani and another species referred to as F. moniliforme were isolated from A. cruentus grains in Argentina [19]. All previous studies were based on morphology, and novel species in Fusarium could, therefore, have been missed.

Recent surveys of newly established A. cruentus fields in two areas of South Africa, and of associated weevils and their damage, yielded numerous Fusarium species isolated from the insects and their galleries in the plants [22]. During preliminary identifications using DNA sequences of the translation elongation factor $1 \alpha$ gene region (TEF $1 \alpha)$, some of these grouped in distinct clades from other known species in the FFSC (data not shown). Isolates from cankered stems of $A$. hybridus galleries associated with $H$. haerens larvae from a different study [23] also grouped into one of the distinct clades. The present study focused on the characterization of these isolates using multigene phylogenetic analyses and morphological comparisons. The potential of these fungal isolates to cause disease on A. cruentus was also assessed in routine pathogenicity trials.

\section{Materials and Methods}

\subsection{Fungal Isolates}

Single conidial isolates (129) grouping into two novel clades in the FFSC from a previous study [22] were included in the present study (Appendix Table A1). Isolates originated from plants collected from agricultural plots of A. cruentus in Potchefstroom and Taung, North West Province, central South Africa (January 2013 and March 2013). They were isolated (Table 1, Appendix Table A1) from emergence holes and lesions associated with the weevils Athesapeuta dodonis and Baris amaranti, discoloration in tunnels of $H$. haerens and larvae from the larval tunnels of $H$. haerens and adults of Ath. dodonis and B. amaranti (March 2013) from plants with insect damage [22]. An isolate obtained from A. hybridus plants [23] was also included in this study. Selected cultures were stored in $15 \%$ glycerol and sterile distilled water and deposited in the culture collection of the National Collection of Fungi, Biosystematics Division, Plant Protection Research Institute, Pretoria, South Africa (PPRI) (Table 1). Dried cultures of novel species were prepared according to Leslie and Summerell [10] and were deposited in the herbarium of the Agricultural Research Council (ARC), Pretoria, South Africa (PREM) (Table 1).

\subsection{DNA Sequence Comparisons}

DNA was extracted from 1-week-old cultures grown on potato dextrose agar (PDA, $20 \%$, Biolab, Johannesberg, South Africa). Mycelium was scraped from the surface of PDA plates, freeze dried and ground to a fine powder with $2 \mathrm{~mm}$-diameter metal beads in a Qiagen TissueLyser II cell disrupter (Whitehead Scientific, Cape Town, South Africa). DNA was extracted [24], with DNA concentrations determined on a NanoDrop 2000 (Thermo Fisher Scientific, NanoDrop products, Wilmington, DE, USA) and standardized to $10 \mathrm{ng} / \mu \mathrm{L}$. 
Table 1. Isolates used in DNA sequence comparison and pathogenicity trials ${ }^{1}$.

\begin{tabular}{|c|c|c|c|c|c|c|}
\hline Species & Host/Substrate & Origin & $\begin{array}{c}\text { Culture Collection }_{(\mathrm{A})} / \text { Strain } \\
\text { Reference }\end{array}$ & BT GenBank Accession & $\begin{array}{c}\text { TEF1 } \alpha \text { GenBank } \\
\text { Accession }\end{array}$ & $\begin{array}{l}\text { RPB2 GenBank } \\
\text { Accession }\end{array}$ \\
\hline Fusarium acutatum $^{(\mathrm{T})}$ & Unknown & India & NRRL 13308 & U34431 & AF160276 & KR674009 \\
\hline F. agapanthi $(\mathrm{T})$ & Agapanthus praecox & Australia & NRRL 54464 & KU900637 & KU900632 & KU900627 \\
\hline F. andiyazi $(\mathrm{T})$ & Sorghum bicolor & Ethiopia & CBS 119857 & KP662894 & KR071718 & KT154004 \\
\hline F. anthophilum & Hippeastrum sp. & Germany & NRRL 25214 & KU171776 & KF466414 & KU171696 \\
\hline F. begoniae ${ }^{(\mathrm{T})}$ & Begonia elatior & Germany & NRRL 25300 & U61543 & AF160293 & LT996140 \\
\hline F. bulbicola $(\mathrm{T})$ & Nerine bowdenii & Germany & NRRL 13618 & U61546 & AF160294 & KF466404 \\
\hline F. casha ${ }^{1}(\mathrm{~T})$ & $\begin{array}{l}\text { Lesions in Amaranthus } \\
\text { cruentus associated } \\
\text { with Athesapeuta } \\
\text { dodonis and Baris } \\
\text { amaranti weevils }\end{array}$ & South Africa & PPRI 21883/PREM 61342 & MF787255 & MF787261 & MN605059/MN605065 \\
\hline F. casha ${ }^{1}$ & Athesapeuta dodonis & South Africa & PPRI 20462/PREM 61343 & MF787256 & MF787262 & MN605060/MN605066 \\
\hline F. casha ${ }^{1}$ & $\begin{array}{l}\text { Athesapeuta dodonis } \\
\text { Isolated from galleries }\end{array}$ & South Africa & PPRI 20468/PREM 61344 & MF787257 & MF787263 & MN605061/MN605067 \\
\hline F. casha & $\begin{array}{l}\text { in Amaranthus hybridus } \\
\text { associated with } \\
\text { Hypolixus haerens larva }\end{array}$ & South Africa & Blodget et al., 2004 [JB143FS] & МТ304823 & MF787264 & MN605068 \\
\hline F. circinatum $^{(\mathrm{T})}$ & Pinus radiata & USA & NRRL 25331 & U61547 & AF160295 & JX171623 \\
\hline F. coicis $(\mathrm{T})$ & Coix gasteenii & Australia & NRRL 66233 & LT996115 & KP083251 & KP083274 \\
\hline F. curculicola $1(\mathrm{~T})$ & Athesapeuta dodonis & South Africa & PPRI 20458/PREM 61345 & MF787258 & MF787266 & MN605062/MN605069 \\
\hline F. curculicola ${ }^{1}$ & Athesapeuta dodonis & South Africa & PPRI 20464/PREM 61346 & MF787259 & MF787267 & MN605063/MN605070 \\
\hline F. curculicola $^{1}$ & $\begin{array}{l}\text { Isolated from lesion in } \\
\text { Amaranthus cruentus } \\
\text { associated with } \\
\text { Athesapeuta dodonis } \\
\text { weevils }\end{array}$ & South Africa & PPRI 20386/PREM 61347 & MF787260 & MF787268 & MN605064/MN605071 \\
\hline F. denticulatum & Ipomoea batatas & USA & NRRL 25302 & U61550 & AF160269 & LT996143 \\
\hline F. dlaminii $(\mathrm{T})$ & Soil & South Africa & NRRL 13164 & U34430 & AF160277 & KU171701 \\
\hline F. ficicrescens & Ficus carica & Iran & CBS 125181 & KР662897 & KP662900 & KT154003 \\
\hline F. fracticaudum $(\mathrm{T})$ & Pinus maximinoi & Colombia & CBS 137234 & KJ541048 & KJ541058 & LT996144 \\
\hline F. fractiflexum $(\mathrm{T})$ & Cymbidium sp. & Japan & NRRL 28852 & AF160315 & AF160288 & LT575064 \\
\hline F. fredkrugeri $(\mathrm{T})$ & $\begin{array}{l}\text { Melhania acuminata } \\
\text { rhizophere }\end{array}$ & South Africa & CBS 144209 & LT996117 & LT996097 & LT996147 \\
\hline F. fujikuroi & Oryza sativa & Taiwan & NRRL 13566 & U34415 & AF160279 & JX171570 \\
\hline
\end{tabular}


Table 1. Cont.

\begin{tabular}{|c|c|c|c|c|c|c|}
\hline Species & Host/Substrate & Origin & $\begin{array}{c}\text { Culture Collection }_{(\mathrm{A})} / \text { Strain } \\
\text { Reference }\end{array}$ & BT GenBank Accession & $\begin{array}{c}\text { TEF1 } \alpha \text { GenBank } \\
\text { Accession }\end{array}$ & $\begin{array}{l}\text { RPB2 GenBank } \\
\text { Accession }\end{array}$ \\
\hline F. globosum ${ }^{(\mathrm{T})}$ & Zea mays & South Africa & NRRL 26131 & U61557 & AF160285 & KF466406 \\
\hline F. inflexum $(\mathrm{T})$ & Vicia faba & Germany & NRRL 20433 & U34435 & AF008479 & JX171583 \\
\hline F. lactis $(\mathrm{T})$ & Ficus carica & USA & NRRL 25200 & U61551 & AF160272 & LT996149 \\
\hline F. mangiferae & Mangifera indica & India & NRRL 25226 & U61561 & AF160281 & HM068353 \\
\hline F. musae ${ }^{\mathrm{T})}$ & Musa sp. & Honduras & NRRL 25059 & FN545368 & FN552086 & FN552108 \\
\hline F. napiforme ${ }^{(\mathrm{T})}$ & Pennisetum typhoides & South Africa & NRRL 13604 & U34428 & AF160266 & EF470117 \\
\hline F. oxysporum & Pseudotsuga menziesii & USA & NRRL 22902 & U34424 & AF160312 & LT575065 \\
\hline F. parvisorum $(\mathrm{T})$ & Pinus patula & Colombia & CBS 137236 & KJ541055 & KJ541060 & LT996150 \\
\hline F. phyllophilum ${ }^{(\mathrm{T})}$ & Dracaena deremensis & Italy & NRRL 13617 & U34432 & AF160274 & KF466410 \\
\hline F. proliferatum & Cattleya sp. & Germany & NRRL 22944 & U34416 & AF160280 & HM068352 \\
\hline F. pseudocircinatum ${ }^{(\mathrm{T})}$ & Solanum sp. & Ghana & NRRL 22946 & U34427 & AF160271 & LT996151 \\
\hline F. pseudonygamai $(\mathrm{T})$ & Pennisetum typhoides & Nigeria & NRRL 13592 & U34421 & AF160263 & LT996152 \\
\hline F. ramigenum $(\mathrm{T})$ & Ficus carica & USA & NRRL 25208 & U61554 & AF160267 & KF466412 \\
\hline F. sacchari & Saccharum officinarum & India & NRRL 13999 & U34414 & AF160278 & JX171580 \\
\hline F. subglutinans & Zea mays & USA & NRRL 22016 & U34417 & AF160289 & JX171599 \\
\hline F. succisae & Succisa pratensis & Germany & NRRL 13613 & U34419 & AF160291 & LT996154 \\
\hline F. sudanense ${ }^{(\mathrm{T})}$ & Striga hermonthica & Sudan & CBS 454.97 & KU603909 & KU711697 & LT996155 \\
\hline F. temperatum & Unknown & Unknown & UNRC RCFT0983 & KP270978 & KР270949 & KP270986 \\
\hline F. terricola $(\mathrm{T})$ & Soil & Australia & CBS 483.94 & KU603908 & KU711698 & LT996156 \\
\hline F. thapsinum & Sorghum bicolor & South Africa & NRRL 22045 & U34418 & AF160270 & JX171600 \\
\hline F. tjaetaba $(\mathrm{T})$ & Sorghum interjectum & Australia & NRRL 66243 & LT996119 & KР083263 & KP083275 \\
\hline F. tupiense & Unknown & Spain & UMAF F1194 & KP753392 & KP753406 & KP753446 \\
\hline F. udum & Lactarius pubescens & Germany & NRRL 22949 & U34433 & AF160275 & LT996172 \\
\hline F. verticillioides & Zea mays & Germany & NRRL 22172 & U34413 & AF160262 & EF470122 \\
\hline F. volatile ${ }^{(\mathrm{T})}$ & $\begin{array}{c}\text { Human bronchoalveolar } \\
\text { lavage liquid }\end{array}$ & French Guiana & CBS 143874 & LR596008 & LR596007 & LR596006 \\
\hline F. xylarioides & Coffea sp. & Ivory Coast & NRRL 25486 & AY707118 & AY707136 & JX171630 \\
\hline
\end{tabular}

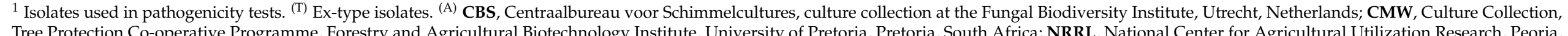

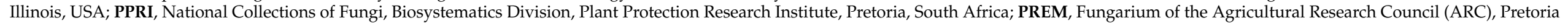
South Africa; UNRC, Department of Microbiology and Immunology, National University of Rio Cuarto, Argentina. 
Three gene regions shown to be sufficient for species delimitation in the FFSC $[3,8,9]$ were amplified on a $\mathrm{T} 100^{\mathrm{TM}}$ Thermal Cycler (Bio-Rad, Johannesburg, South Africa). The TEF1 $\alpha$ region was amplified using primers EF1 and EF2 [25]; the $\beta$-tubulin 2 region of the B-tubulin (BT) gene was amplified using primers T1 and T2 [26]; and two non-contiguous fragments of the RNA polymerase II subunit (RPB2) were amplified using primer sets RPB2$5 f 2 / 7 \mathrm{cr}$ and RPB2-7cf/11ar, respectively $[27,28]$. In order to characterize the 129 isolates suspected to represent the two species (Appendix Table A1), only the TEF1 $\alpha$ gene was first sequenced [25] to group them into two distinct clades named Clade A and B (data not shown). Three isolates were then randomly selected to represent each clade for further sequencing of the BT and RPB2 genes. The isolate from Blodgett et al. [23] was also included in the multigene analyses.

Reactions were performed in a total volume of $25 \mu \mathrm{L}$, consisting of 40 ng DNA template, $0.25 \mu \mathrm{L}(1 \mu \mathrm{M})$ of each primer, $12.5 \mu \mathrm{L}$ EconoTaq PLUS GREEN $2 \times$ Master Mix $(1 \times)$ (Lucigen corporation, Middleton, WI, USA) and $8 \mu \mathrm{L}$ nuclease-free water (WhiteSci, Cape Town, South Africa). The PCR program included an initial denaturation step of $95^{\circ} \mathrm{C}$ for $3 \mathrm{~min}$ followed by 40 amplification cycles consisting of $95^{\circ} \mathrm{C}$ for $30 \mathrm{~s}, 61.3^{\circ} \mathrm{C}$ (TEF1 $\alpha), 52{ }^{\circ} \mathrm{C}(\mathrm{BT})$ or $62.3^{\circ} \mathrm{C}$ (RPB2-5f2/7cr) and $62.3^{\circ} \mathrm{C}$ (RPB2-7cf/11ar) for $30 \mathrm{~s}$, and $72{ }^{\circ} \mathrm{C}$ for $50 \mathrm{~s}$, followed by a final extension step at $72{ }^{\circ} \mathrm{C}$ for $5 \mathrm{~min}$. PCR products were viewed with UV light on $2 \%$ agarose gels with GelRed ${ }^{\mathrm{TM}}$ (Anatech, Johannesburg, South Africa). PCR products were cleaned enzymatically by adding $10 \mu \mathrm{L}$ of PCR product to 0.5 $\mu \mathrm{L}(10 \mathrm{u})$ of Exonuclease I (Fermentas, Nunningen, Germany), and $2 \mu \mathrm{L}(2 \mathrm{u})$ of FastAP ${ }^{\mathrm{TM}}$ Thermosensitive Alkaline Phosphatase (Fermentas, Germany) at $37^{\circ} \mathrm{C}$ for $15 \mathrm{~min}$. The enzymes were inactivated at $85^{\circ} \mathrm{C}$ for $15 \mathrm{~min}$ and cooled to $4{ }^{\circ} \mathrm{C}$. The same primers as those used in the PCR amplification were used for $\mathrm{BT}$ and RPB2, but for the TEF1 $\alpha$ region, internal primers EF3 and EF22T were used [25]. An ABI Prism BigDye ${ }^{\circledR}$ terminator v. 3.1 Cycle Sequencing kit (Applied Biosystems, Foster City, CA, USA) was used according to the manufacturer's instructions on an ABI Prism ${ }^{\mathrm{TM}} 3100$ DNA sequencer (Applied Biosystems). Sequences obtained were viewed and edited, if required, with GENEIOUS 7.1.9 (Biomatters Limited, Auckland, New Zealand).

Sequences were aligned with currently legitimate species and phylogenetic lineages in the FFSC for which sequences were available $[3,5,16,17]$ (Table 1) using MAFFT 7.0 (http:/ / mafft.cbrc.jp/alignment/software/, accessed on 31 October 2020) with the L-INS-I option selected [29-32]. Fusarium oxysporum and F. inflexum were used as outgroup species since they represent closely related, but different, species complexes. The alignments were corrected manually if required, and novel sequences were deposited in GenBank (Table 1).

Phylogenetic analyses were performed with the software package PAUP* $4.01 \mathrm{~b} 10$. Phylogenetic analyses were conducted for each gene region separately, as well as combined, as previously described $[3,14-16,33]$. Analyses were conducted with maximum parsimony (MP) (heuristic search with 100 random sequence additions). A 1000 bootstrap replication test was performed to determine the support of branches [34] of the most parsimonious tree for the various dataset combinations. This was conducted after the exclusion of uninformative sites, with the heuristic search with 100 random sequence additions and tree bisection reconnection (TBR) branch swapping selected, and MAXTREES set to 1000 to allow for the completion of analysis.

Additional phylogenetic analyses were conducted based on maximum likelihood (ML) and Bayesian inference (BI). The correct models for the datasets were identified using jModeltest 0.0.1 [35]. The TrN $+\mathrm{G}$ model [36] was shown to be appropriate for the TEF1 $\alpha$ dataset, the TIM2 +G model for the BT and RPB2 datasets [35] and the TIM2ef+G model for the combined dataset [37] (Table 2). Maximum likelihood analyses were performed with PhyML 3. A 1000-replicate bootstrap analysis was conducted to assess the confidence of the branch nodes in the phylogenetic trees. Bayesian analyses were performed with the MrBayes plug-in for GENEIOUS 7.1.9 using the same evolutionary model, a chain length of 1,100,000 for four heated chains and a burn-in of 20,000. 
Table 2. Statistics resulting from maximum parsimony analyses and jModeltest 0.0.1.

\begin{tabular}{ccccc}
\hline Statistics & BT & TEF1 $\alpha$ & RPB2 & Combined BT, TEF1 $\alpha$ and RPB2 \\
\hline Number of sequences & 53 & 53 & 53 & 53 \\
Aligned characters & 505 & 668 & 1637 & 2810 \\
Parsimony-informative characters & 82 & 161 & 236 & 479 \\
Tree length & 164 & 496 & 734 & 1507 \\
Consistency index (CI) & 0.750 & 0.550 & 0.377 & 0.447 \\
Retention index (RI) & 0.939 & 0.810 & 0.682 & 0.746 \\
Model & TrN+G & TIM2+G & TIM2+G & TIM2ef+G \\
Gamma shape & 0.4850 & 0.3570 & 0.1430 & 0.2160 \\
P-inv & No & No & No & No \\
\hline
\end{tabular}

\subsection{Morphology}

To study the morphology of the two new species, the three single conidial isolates (Table 1) selected as representative isolates for each of the two novel clades observed (PPRI 21883, PPRI 20468 and PPRI 20462, and PPRI 20458, PPRI 20386 and PPRI 20464, respectively) were grown on synthetic low-nutrient agar (SNA) [38] and carnation leaf agar (CLA) [39], unwrapped, for 7 to $14 \mathrm{~d}$ at $25{ }^{\circ} \mathrm{C}$ under near-ultraviolet light $[6,40]$. Fungal structures formed were mounted on microscope slides in $85 \%$ (vol/vol) lactic acid (Sigma-Aldrich, St Louis, MI, USA) or were examined directly on agar by cutting out a small block of agar and placing it on a microscope slide. Fifty measurements were recorded for each character. Measurements and photographs were captured with an Olympus BX53 light microscope and DP75 camera (Olympus, South Africa). Illustrations were prepared by free hand by observing morphology on SNA and CLA carefully.

Colony characteristics and growth rates of the unknown clades were determined for the same three representative single conidial isolates of each clade as used for the microscopic study (Table 1). Discs were taken from the edges of actively growing cultures on PDA and transferred to the centers of $90 \mathrm{~mm}$ Petri dishes containing PDA. Five plates per isolate were placed in the dark and incubated at $15-35^{\circ} \mathrm{C}$ at five degree intervals. The average growth rate per day was calculated for each isolate by performing two perpendicular measurements of the growth diameter, each day, until the fastest-growing culture had covered the surface of the plate. The trial was repeated once. Analysis of variance (ANOVA; $\alpha=0.05$ ) of the data was performed using base $\mathrm{R}$ functions to test if results from the two trials could be pooled, and no significant difference was observed between the trails. Pooled data were analyzed with means separated using an adjusted Bonferroni test function from the 'agricolae' package, in order to account for the potential family-wise error rate [41], as more than three groups were being compared. Colony characters were also recorded under near-UV light at $25^{\circ} \mathrm{C}$. Colony colors were described using the charts of Rayner [42].

\subsection{Pathogenicity}

Pathogenicity experiments were conducted with the same isolates used for the phylogenetic and morphological studies (Table 1). Amaranthus cruentus plants were established in a greenhouse at $27 / 21^{\circ} \mathrm{C}$ day/night conditions, which are optimal for the growth and germination of the plant [43]. Seeds were sown in $2 \mathrm{~L}$ pots lined with plastic bags, with a soil compost mix (80:20 vol/vol), and watered to field capacity. Plastic bags were sealed and opened at seedling emergence ( $3-5$ d). At 6 weeks, plants were thinned to three plants per pot. Pots were watered daily to field capacity and were fertilized at 10 weeks with Nutrifeed (Starke Ayres, Bredell, South Africa) (65 g/kg N, 27 g/ kg P, 130 g/kg K, 70 g/kg Ca, 22 g/kg $\mathrm{Mg}, 75 \mathrm{mg} / \mathrm{kg} \mathrm{S}, 1500 \mathrm{mg} / \mathrm{kg} \mathrm{Fe}, 240 \mathrm{mg} / \mathrm{kg} \mathrm{Mn}, 240 \mathrm{mg} / \mathrm{kg} \mathrm{B}, 20 \mathrm{mg} / \mathrm{kg} \mathrm{Cu}$ and $10 \mathrm{mg} / \mathrm{kg}$ Mo) as per the instructions of the supplier. Plants were cultivated for 12 weeks.

Ten plants were inoculated with each isolate after 12 weeks. A small section $(5 \times 5 \mathrm{~mm})$ of the epidermis of the stem was removed with a scalpel, and an agar plug cut from an actively growing culture was placed mycelium-side-down into the wound [23,44]. Non-colonized agar 
plugs were applied as controls. To prevent desiccation of agar plugs, wounds were sealed with a strip of Parafilm (Sigma-Aldrich, Johannesburg, South Africa) [23,44]. The length of lesions formed was measured (if present) after four weeks. The trial was repeated once. Pieces were cut from the margins of necrotic tissues and placed on CLA and PDA to re-isolate the inoculated fungus. The identities of the re-isolated cultures were confirmed by studying the morphology and TEF1 $\alpha$ sequencing.

Analysis of variance (ANOVA; $\alpha=0.05$ ) of the data was performed using base $\mathrm{R}$ functions. ANOVA was applied to determine if experimental replicates differed significantly. Trials differed significantly and were thus not pooled for further analyses. Means were separated using an adjusted Bonferroni test function from the 'agricolae' package [41], as there were more than three groups being compared. Data processing and analyses were performed with $\mathrm{R}$ version 4.0.2 [45] within $\mathrm{R}$ Studio version 1.2.5042 [46]. Data exploration, wrangling and visualization were conducted using the 'Tidyverse' package [47].

\section{Results}

\subsection{Fungal Isolates}

A total of 129 isolates were obtained that grouped into two novel clades in the FFSC based on preliminary TEF1 $\alpha$ sequence identities (Appendix Table A1). This included two isolates from Blodgett et al. [23] from galleries in A. hybridus associated with $H$. haerens larvae, and cankered stems of $A$. hybridus from Bloemfontein. The remaining 127 isolates [22] included 66 isolates from lesions below the emergence holes of Ath. dodonis and $B$. amaranti (Clade $\mathrm{A}=23$, Clade $\mathrm{B}=43$ ), 12 from larval galleries of $H$. haerens (Clade $\mathrm{A}=2$, Clade $\mathrm{B}=10), 3$ from $H$. haerens larvae (Clade $\mathrm{A}=1$, Clade $\mathrm{B}=2$ ), 43 from Ath. dodonis (Clade $\mathrm{A}=12$, Clade $\mathrm{B}=31$ ) and 3 from B. amaranti (Clade $\mathrm{A}=1$, Clade $\mathrm{B}=2$ ) adults (Figure 1 ).

\subsection{DNA Sequence Comparisons}

Seven isolates representing the two novel clades were included for final phylogenetic analysis (Table 1, Figure 1). These included one isolate from Blodgett et al. [23], and six representative isolates [22] based on the preliminary phylogenetic analyses of TEF1 $\alpha$ for all isolates. The datasets for TEF1 $\alpha$, ST and RPB2 and the combined dataset consisted of 53 taxa (Table 2). The alignment lengths of TEF1 $\alpha$, BT and RPB2 were 668, 505 and 1637 bp in length, respectively, and the combined alignment was 2810 bp long (Table 2).

Maximum parsimony, ML and BI analyses of the three datasets (data not shown) generated trees with similar topologies and resembled the phylogenetic positions of those previously published for the TEF1 $\alpha$, BT, RPB2 and combined datasets $[3,8,9,11,14,16,33]$. The three distinct clades known in the FFSC, namely, the African, American and Asian clades, were observed. Isolates from this study all grouped into the African clade.

Analysis of the combined as well as separate datasets grouped isolates from this study and those from Blodgett et al. [23] into two distinct groups within the African clade (Figure 1). The two clades can be recognized as distinct species when including morphological characteristics (below). The first clade consisted of isolates from Ath. dodonis and B. amaranti adults, H. haerens larvae, lesions below emergence holes of Ath. dodonis and B. amaranti and larval galleries of $H$. haerens in A. cruentus (Clade A, Figure 1) (bootstrap confidence levels for combined TEF1- $\alpha$, BT and RPB2 gene sequences ML/MP/BI, Figure 1, 100/100/99). They grouped closely with a clade containing F. volatile (84/94/99) and F. coicis (100/100/99) (Clade A, Figure 1), and F. musae and F. verticillioides (100/100/99). The other well-supported clade consisted of an isolate from Blodgett et al. [23], and those isolated from Ath. dodonis and $B$. amaranti adults, $H$. haerens larvae, lesions below emergence holes of Ath. dodonis and B. amaranti and larval galleries of $H$. haerens in A. cruentus (Clade B, Figure 1) (100/100/99). This clade grouped closely with one containing F. tjaetaba (100/100/99), F. napiforme (_/84/99) and F. ramigenum (98/100/99) (Clade B, Figure 1).

\subsection{Taxonomy}

Fusarium casha M. Verm. \& Gryzenh., sp. nov. Figure 2A-F and Figure 3. 


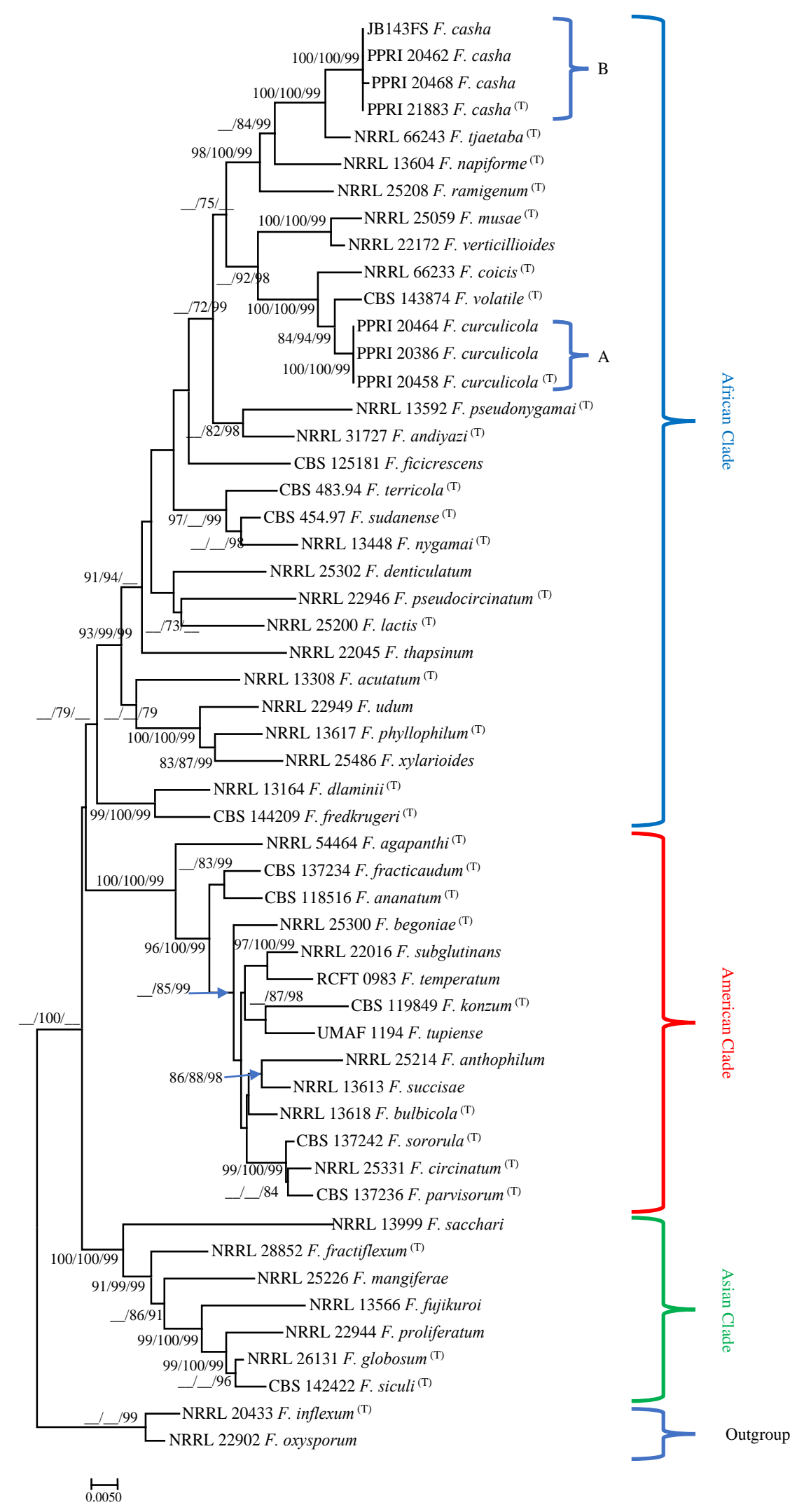

Figure 1. Phylogram obtained from maximum likelihood analyses for combined TEF1 $\alpha, B T$ and RPB2 gene sequences, obtained using the TIM2ef $+\mathrm{G}$ parameter model. For all trees, confidence levels $>70 \%$ (1000-replicate bootstrap analysis) of the tree branch nodes, determined by ML and MP, and posterior probabilities for Bayesian inference (BI) are indicated on tree branches (ML/MP/BI). Fusarium inflexum and F. oxysporum are defined as the outgroup taxa. 

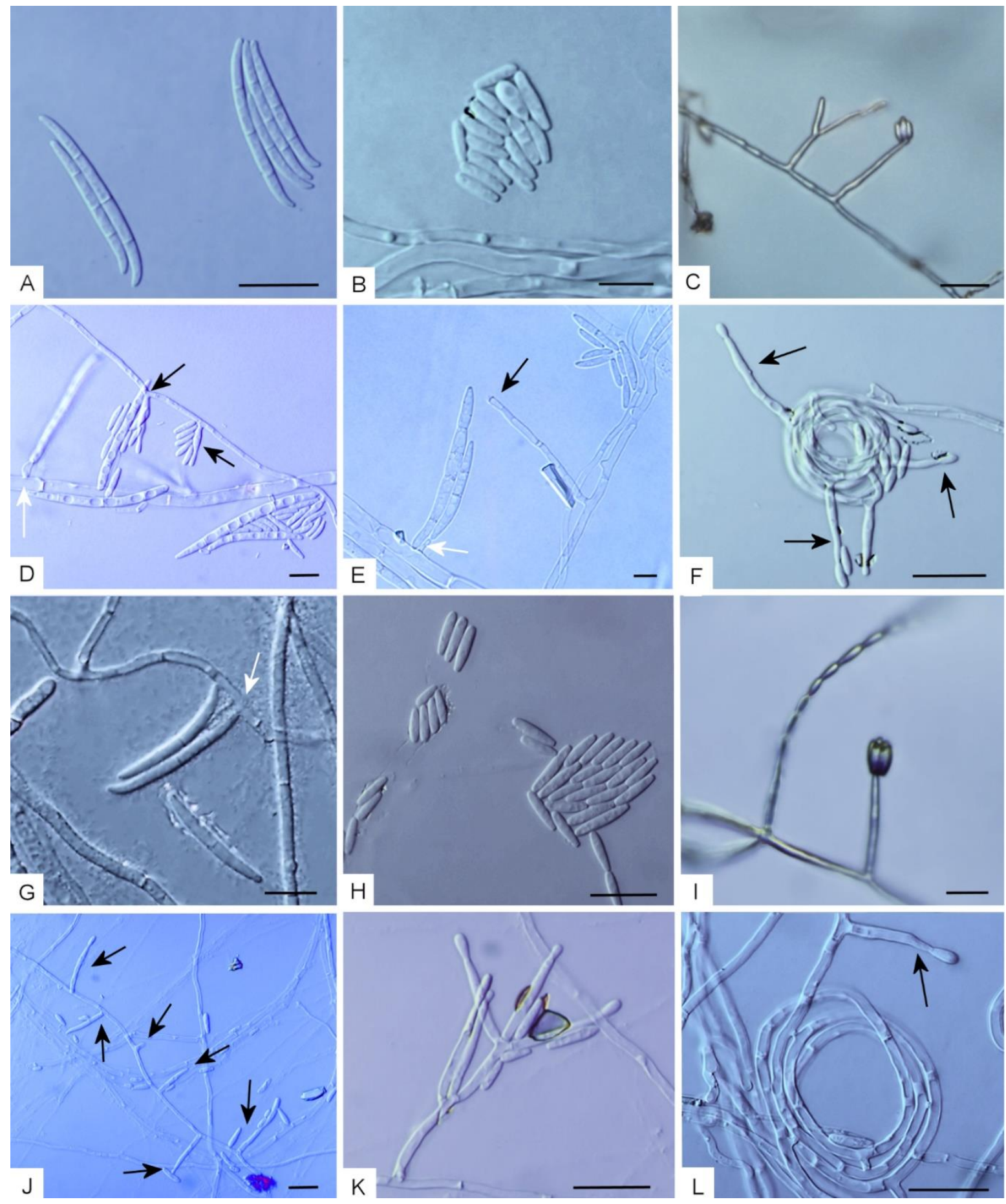

Figure 2. (A-F) Morphological characters of Fusarium casha on carnation leave agar (CLA). (A) Macroconidia. (B) Microconidia. (C) Microconidia produced in false heads. (D,E) Conidiogenous cells forming micro- and macroconidia (conidiogenous cells forming macroconidia indicated in white arrows). (F) Substrate hyphae bearing conidiogenous cells coiling into circles. (G-L) Morphological characters of F. curculicola on CLA. (G) Macroconidia (conidiogenous cell indicated with a white arrow). (H) Microconidia. (I) Microconidia produced in a false head (right) and a chain (left). (J) Conidiogenous cells (arrows). (K) A conidiophore. (L) Hyphae bearing a conidiogenous cell coiling into circles. Bars: $10 \mu \mathrm{m}$. 


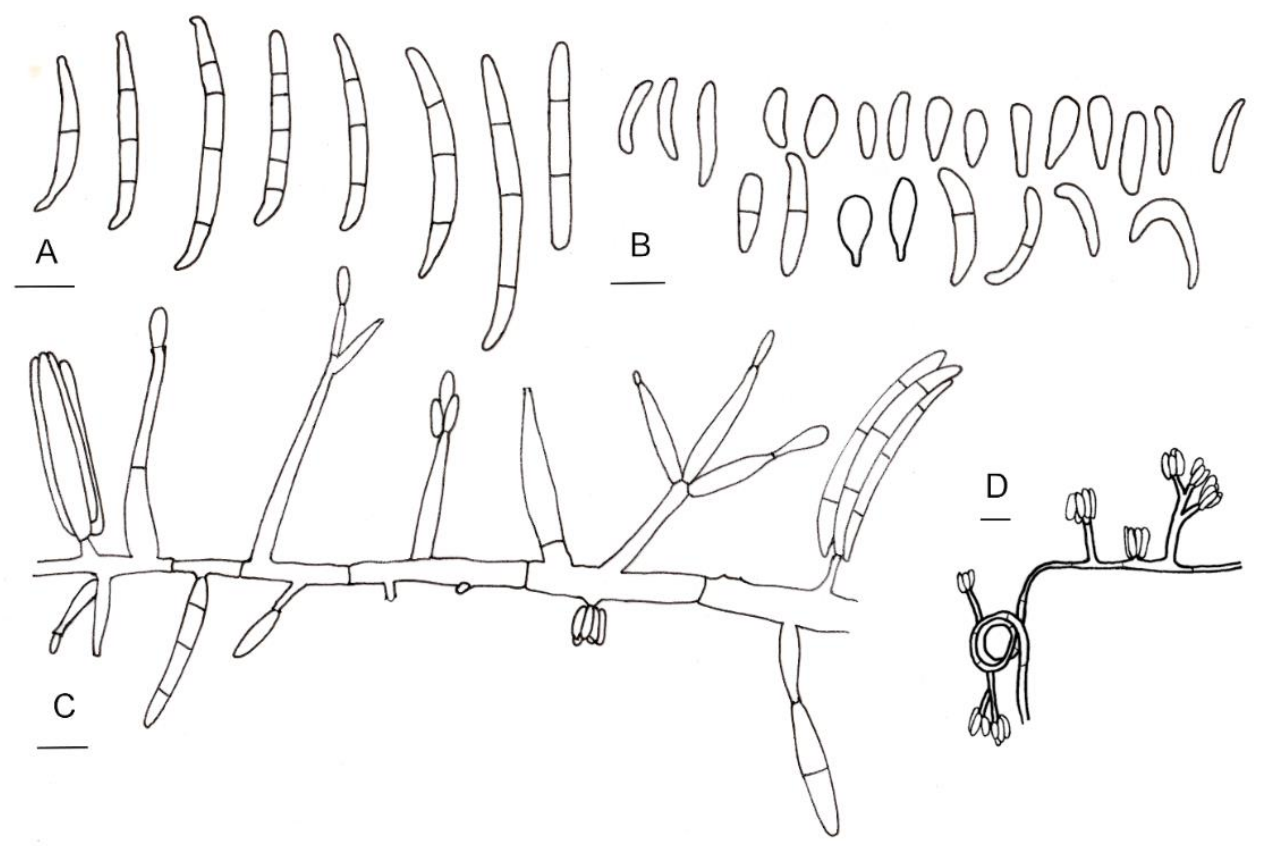

Figure 3. Line drawings of morphological characters of Fusarium casha. (A) Macroconidia. (B) Microconidia. (C) Conidiophores and conidiogenous cells. (D) Conidia produced in false heads and hyphae coiling in circles. Bars: $5 \mu \mathrm{m}$.

MycoBank no.: MB 822523.

Diagnosis: Macroconidia slender, straight to slightly curved, with $0-5$ septa, apical cell blunt to papillate, basal cells notched to distinctly notched; microconidia oval, short clavate, ellipsoid, curved, c-shaped to obpyriform; aseptate rarely single septate; conidiogenous cells only monophialidic, can be borne on conidiophores, forming only false heads, orthophialidic or pleurophialidic on running hyphae. Chlamydospores absent.

Type: South AfricA, Potchefstroom, North West Province, isolated from lesions in Amaranthus cruentus associated with Athesapeuta dodonis and Baris amaranti weevil emergence holes, 2013, M. Vermeulen, holotype PREM 61342, ex-type culture PPRI 21883.

Gene sequences ex-holotype: MF787257 ( $\beta T)$, MF787263 (TEF1 $\alpha)$, MN605061/ MN605067 (RPB2).

Etymology: The species name 'casha' denotes the Zulu for 'hiding' since it was first isolated from cankered stems and Hypolyxis haerens larval galleries in Amaranthus hybridus by Blodgett et al. [23]. At that time, it was only identified based on morphology, and this new species has, therefore, been 'hiding' and remained undescribed since 2004.

Macroconidia on CLA abundant to absent, slender, straight to slightly curved, 20.5-80.0 $\times 2.0-6.5 \mu \mathrm{m}$ (avg. $39.1 \times 3.3 \mu \mathrm{m})$, with $0-5$ septa, most abundantly with 0-3 septa, occasionally, septa are irregularly placed, apical cell blunt to papillate, 10.0-30.0 $\mu \mathrm{m}$ long (avg. $14.4 \mu \mathrm{m}$ ), basal cells notched to distinctly notched, 10.0-36.0 $\mu \mathrm{m}$ long (avg. 14.2 $\mu \mathrm{m}$ ). Microconidia on CLA abundant, aseptate, can be single septated, oval, short clavate, ellipsoid, curved to c-shaped, $6.0-25.0 \times 2.0-4.0 \mu \mathrm{m}$ (avg. $10.9 \times 2.8 \mu \mathrm{m}$ ), or obpyriform, 6.5-11.5 $\times$ 2.0-5.5 $\mu \mathrm{m}$ (avg. $9.2 \times 3.9 \mu \mathrm{m}$ ), on SNA abundant, oval to curved, 7.5-16.0 $\times 1.5-3.0 \mu \mathrm{m}$ (avg. $10.3 \times 2.2 \mu \mathrm{m}$ ), obpyriform microconidia $6.0-11.5 \times 2.5-6.5 \mu \mathrm{m}$ (avg. $8.2 \times 3.9 \mu \mathrm{m}$ ). Conidiogenous cells forming macroconidia only monophialidic, varying from orthophialidic up to $21 \mu \mathrm{m}$ long, to pleurophialidic on running hyphae on both CLA and SNA; conidiogenous cells forming microconidia only monophialidic, varying from orthophialidic to pleurophialidic on running hyphae or can be borne in conidiophores, on CLA 13.0-48.5 $\mu \mathrm{m}$ long (avg. $25.8 \mu \mathrm{m}$ ), on SNA 9.5-32.5 $\mu \mathrm{m}$ long (avg. $22.4 \mu \mathrm{m}$ ). Microconidia arranged only in false heads on CLA and SNA, aerial mycelium abundant, white (-/9.4-10.0/0-0.8) to pale luteous $(2.4 \mathrm{Y} / 8.5 / 7.0)$, substrate mycelium occasionally forming coiling circles. Chlamydospores absent. Culture characteristics: On PDA colonies showed optimal growth at $25^{\circ} \mathrm{C}$ (Table 3), average growth rate at $25^{\circ} \mathrm{C}$ of $6.25 \mathrm{~mm} / \mathrm{d}$ for PPRI 21883, $10.31 \mathrm{~mm} / \mathrm{d}$ for PPRI 20468 and $8.63 \mathrm{~mm} / \mathrm{d}$ for 
PPRI 20462 after $8 \mathrm{~d}$. Growth was observed at all temperatures but was limited at $10{ }^{\circ} \mathrm{C}$ and $35^{\circ} \mathrm{C}$ (Table 3). Reverse on PDA in near-UV light, straw $(7.5 \mathrm{Y} / 8.7 / 4.1)$ to pale luteous with edges livid vinaceous $(0.9 \mathrm{R} / 5.2 / 4.2)$ to dark brick $(0.2 \mathrm{YR} / 3.9 / 4.2)$, and in the dark, straw to vinaceous gray $(6.0 \mathrm{RP} / 4.4 / 2.3)$ to dark brick.

Table 3. Results of growth studies conducted on Fusarium casha and F. curculicola.

\begin{tabular}{|c|c|c|c|c|c|c|c|c|}
\hline \multirow{2}{*}{ Species } & \multirow{2}{*}{$\begin{array}{l}\text { Isolate } \\
\text { Number }\end{array}$} & \multicolumn{6}{|c|}{ Average Growth $(\mathrm{mm})$ at Different Incubation Temperatures after Day 8} & \multirow{2}{*}{$\begin{array}{c}\text { Average } \\
\text { Growth/d } 25{ }^{\circ} \mathrm{C}\end{array}$} \\
\hline & & $10^{\circ} \mathrm{C}$ & $15^{\circ} \mathrm{C}$ & $20{ }^{\circ} \mathrm{C}$ & $25^{\circ} \mathrm{C}$ & $30{ }^{\circ} \mathrm{C}$ & $35^{\circ} \mathrm{C}$ & \\
\hline Fusarium casha & PPRI 21883 & $9.1^{\mathrm{n}}$ & $26.6^{\mathrm{k}}$ & $40.5^{\mathrm{i}}$ & $50 \mathrm{fgh}$ & $41.9^{\mathrm{i}}$ & $11.1 \mathrm{mn}$ & 6.25 \\
\hline F. casha & PPRI 20462 & $11.4^{\operatorname{lmn}}$ & $27.6^{\mathrm{jk}}$ & $51.1^{\mathrm{fg}}$ & $69.1^{\mathrm{b}}$ & 50.7 fgh & $8.5^{\mathrm{n}}$ & 8.63 \\
\hline F. casha & PPRI 20468 & $12.2^{\operatorname{lmn}}$ & $31.4^{\mathrm{j}}$ & $65.9^{b c}$ & $82.5^{\mathrm{a}}$ & $65.8^{\mathrm{bc}}$ & $13.9^{\mathrm{lm}}$ & 10.31 \\
\hline F. curculicola & PPRI 20386 & $9.1^{\mathrm{n}}$ & $27.2^{\mathrm{jk}}$ & $50.4^{\text {fgh }}$ & 60.9 de & $59.9^{\mathrm{e}}$ & $14^{\operatorname{lm}}$ & 7.62 \\
\hline F. curculicola & PPRI 20458 & $8.0^{\mathrm{n}}$ & $28.5^{\mathrm{jk}}$ & $53.9^{f}$ & $82.2^{\mathrm{a}}$ & $64.6^{\mathrm{cd}}$ & $15.5^{1}$ & 10.28 \\
\hline F. curculicola & PPRI 20464 & $9.8^{\mathrm{mn}}$ & $26.1^{\mathrm{k}}$ & $47.8 \mathrm{gh}$ & $61.8^{\text {cde }}$ & $46.7 \mathrm{gh}$ & $11.2 \mathrm{mn}$ & 7.73 \\
\hline
\end{tabular}

Least significant difference determined through Bonferroni $(\alpha=0.05)$ : Isolate $\times$ Temperature $=4.29\left({ }^{a-n}\right)$. No statistical difference between trials one and two $(p>0.05)$; data were therefore combined. PPRI, National Collections of Fungi, Biosystematics Division, Plant Protection Research Council, Pretoria, South Africa.

Habitat and distribution: Amaranthus species and associated weevils such as Ath. dodonis, B. amaranthi and H. haerens, South Africa.

Additional specimens examined: SOUTH AfricA, Taung, North West Province, isolated from Ath. dodonis, 2013, M. Vermeulen, PREM 61344 and PREM 61343, living cultures PPRI 20468 and PPRI 20462, respectively.

Fusarium curculicola M. Verm. \& Gryzenh., sp. nov. Figure 2G-L and Figure 4.

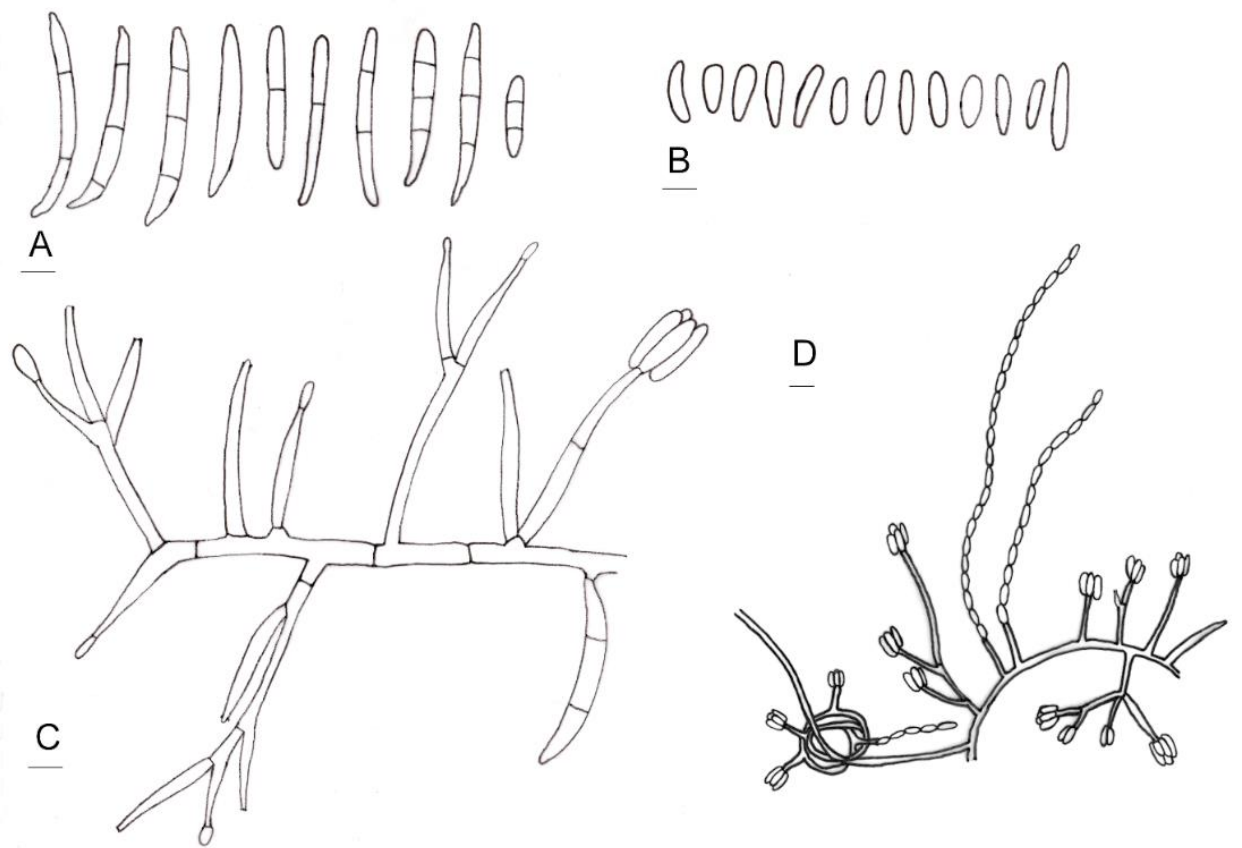

Figure 4. Line drawings of morphological characters of Fusarium curculicola. (A) Macroconidia. (B) Microconidia. (C) Conidiophores and conidiogenous cells. (D) Conidia produced in false heads and hyphae coiling in circles. Bars: $5 \mu \mathrm{m}$.

MycoBank no.: MB 822524.

Diagnosis: Macroconidia slender, straight to slightly curved, with 0-3 septa, apical cells blunt to slightly papillate, basal cells notched; microconidia oval to obovoid, ellipsoid, short clavate, fusiform; conidiogenous cells only monophialidic, borne on the apical tip of conidiophores or their branches, forming false heads and long false chains, pleurophialidic, formed intercalary on running hyphae. Chlamydospores absent. 
Type: SOUTH AFRICA, Potchefstroom, North West Province, isolated from Athesapeuta dodonis, 2013, M. Vermeulen, holotype PREM 61345, ex-type culture PPRI 20458.

Gene sequences ex-holotype: MF787258 ( $\beta$ T), MF787266 (TEF1 $\alpha)$, MN605062/ MN605069 (RBPB2).

Etymology: Curculi- (Latin) refers to weevils, indicating its close association implied by the direct isolation from the insect and related damage, and -cola means dweller or inhabiting.

Macroconidia on CLA scarce to absent, slender, straight to slightly curved, 11.5-55.5 × 2.0-6.5 $\mu \mathrm{m}$ (avg. $30.7 \times 3.4 \mu \mathrm{m})$, with 0-3 septa, apical cells blunt to slightly papillate, 9.5-25.0 $\mu \mathrm{m}$ long (avg. $13.3 \mu \mathrm{m})$, basal cells notched, 6.5-26.0 $\mu \mathrm{m}$ (avg. $13.0 \mu \mathrm{m})$. Microconidia on CLA abundant, aseptate, oval to obovoid, ellipsoid, short clavate or fusiform, 8.5-18.0 × 2.0-3.5 $\mu \mathrm{m}$ (avg. $12.1 \times 2.7 \mu \mathrm{m})$, on SNA abundant, oval to obovoid, 6.0-14.0 $\times 2.0-3.0 \mu \mathrm{m}($ avg. $9.8 \times 2.6 \mu \mathrm{m})$. Conidiogenous cells forming macroconidia only monophialidic, varying from orthophialidic cells up to $12 \mu \mathrm{m}$ long to pleurophialidic on running hyphae on both CLA and SNA; conidiogenous cells forming microconidia only monophialidic, orthophialidic to pleurophialidic on running hyphae, can be borne in conidiophores, intercalary phialides present, on CLA 14.0-51.0 $\mu \mathrm{m}$ long (avg. $29.7 \mu \mathrm{m})$, on SNA 11.5-49.0 $\mu \mathrm{m}$ long (avg. $25.6 \mu \mathrm{m}$ ). Aerial and substrate mycelium present with microconidia arranged in false heads and long chains of more than 20 conidia on CLA and SNA, aerial mycelium abundant, white (-/9.4-10.0/0-0.8) to peach $(10 \mathrm{OR} / 7.2 / 8.5)$, substrate mycelium occasionally forming coiling circles bearing conidiophores. Chlamydospores absent. Culture characteristics: PDA colonies show optimal growth at $25^{\circ} \mathrm{C}$ (Table 3), with an average growth rate at $25^{\circ} \mathrm{C}$ of $7.62 . \mathrm{mm} / \mathrm{d}$ for PPRI 20386, $10.28 \mathrm{~mm} / \mathrm{d}$ for PPRI 20458 and $7.73 \mathrm{~mm} / \mathrm{d}$ for PPRI 20464 after 8 d. Growth was observed at all temperatures, but was limited at $10^{\circ} \mathrm{C}$ and $35^{\circ} \mathrm{C}$ (Table 3). Reverse colony color on PDA in near-UV, light uniform peach to saffron (7.1YR/8.0/9.0), and in the dark, straw to vinaceous gray (6.0RP/4.4/2.3) and dark brick (0.2YR/3.9/4.2).

Habitat and distribution: Amaranthus species and associated weevils such as Ath. dodonis and B. amaranthi, South Africa.

Additional specimens examined: SOUTH AFRICA, Taung, North West Province, isolated from lesions in A. cruentus associated with Ath. dodonis and B. amaranthi weevil emergence holes, 2013, M. Vermeulen, PREM 61347, living culture PPRI 20386, and isolated from an Ath. dodonis adult, 2013, M. Vermeulen, PREM 61346, living culture PPRI 20464.

\section{Taxonomic Notes}

Fusarium casha is closely related to F. napiforme, F. ramigenum and F. tjaetaba based on the phylogenetic analyses but can be morphologically distinguished from these species. Macroconidia of $F$. casha (apical cell = blunt to papilate, basal cell = notched to distinctly notched), F. ramigenum (apical cell = bent, basal cell = notched) [10], F. napiforme (apical cell $=$ tapering to slightly curved, basal cell $=$ foot-shaped) $[48]$ and $F$. tjaetaba (apical cell = hooked, basal cell = distinctly notched) [6] can be differentiated based on the morphology of the apical and basal cells. Microconidia of F. casha are oval, short clavate, ellipsoid, curved to c-shaped, occasionally obpyriform and mostly non-septate. Those of F. ramigenum [49] and F. napiforme [48] are broadly obovoid, mostly aseptate and variable in shape with 0-3 septa, respectively. Fusarium napiforme also produces lemon-shaped and napiform microconidia [48], and F. tjaetaba has 0-1 septate pyriform and oval spore [6]. More obvious is the fact that F. casha and F. tjaetaba only produce conidia in false heads, while F. napiforme produces long chains and F. ramigenum short chains $[10,49]$. Conidiogenous cells of F. ramigenum and F. tjaetaba are mono- and polyphialidic, while those of F. casha and F. napiforme are only monophialidic $[6,10,48,49]$. Of these species, F. casha and F. ramigenum are the only species that do not produce chlamydospores.

Fusarium curculicola can be morphologically distinguished from phylogenetically closely related species F. volatile, F. coicis, F. musae and F. verticillioides. Macroconidia in F. curculicola and F. volatile (9) are 0-3 septate, while those in F. verticillioides [38] are 
3-5 septate, absent in F. musae [50] and very long and usually 7 septate in F. coicis (can be 4-10 septate) [6]. Fusarium coicis, F. curculicola, F. verticillioides and F. volatile can be differentiated from $F$. musae based on the absence of pseudochlamydospores $[6,9,10,38,50]$. The microconidia of $F$. curculicola can be oval, obovoid, short clavate or ellipsoid to fusiform, while those in F. coicis, F. musae, F. verticillioides and F. volatile are oval to clavate. Fusarium coicis and F. volatile differ from F. verticillioides and F. curculicola by having up to 3-septate microconidia (usually aseptate in F. verticillioides and F. curculicola), while F. musae is mostly aseptate. Fusarium verticillioides, F. curculicola and F. musae have conidiogenous cells that are only monophialidic, while those of $F$. coicis and F. volatile are mono- and polyphialidic $[6,9,10,38,50]$. Fusarium curculicola and F. musae are also the only two of these species that form intercalary phialides.

\subsection{Pathogenicity}

Lesion lengths from the first and second trial were significantly different $(p>0.05)$, and data were, therefore, analyzed separately (Table 4 ). For the first trial, two of the three isolates for F. casha (Clade B; PPRI 21883 and PPRI 2046) and one of the three isolates for F. curculicola (Clade A; PPRI 20386) formed lesions that were significantly larger $(p<0.05)$ than the measurements for the negative control (Table 4; Control). In the second trial, the same two of the three isolates for F. casha (Clade B) and two of the three for F. curculicola (Clade A; PPRI 20464 and PPRI 20458) formed lesions that were significantly larger $(p<0.05)$ than the measurements for the negative control (Table 4; Control). For wounds of control plants, there was a degree of callus and 1 formation in some of the inoculations (Figure 5A). For both the first and second trials, lesions made by F. casha isolates were not significantly different in size from those made by F. curculicola isolates (Table 4). All fungi were reisolated from lesion margins of the tested A. cruentus plants, and their identities were confirmed, fulfilling Koch's postulates.

Table 4. Results of pathogenicity tests with Fusarium casha and F. curculicola on Amaranthus cruentus.

\begin{tabular}{|c|c|c|c|}
\hline \multirow[b]{2}{*}{ Species } & \multirow[b]{2}{*}{ Isolate Number } & \multicolumn{2}{|c|}{ Mean Lesion Length (mm) } \\
\hline & & Trial 1 & Trial 2 \\
\hline Fusarium casha & PPRI 21883 & $21.73^{a}$ & $19.68^{\mathrm{A}}$ \\
\hline F. casha & PPRI 20462 & $11.28^{\mathrm{c}}$ & $10.88^{C}$ \\
\hline F. casha & PPRI 20468 & $17.35^{a b}$ & $9.36^{\mathrm{CD}}$ \\
\hline F. curculicola & PPRI 20458 & $15.00 \mathrm{bc}$ & $9.68^{C}$ \\
\hline F. curculicola & PPRI 20386 & $17.50^{\mathrm{ab}}$ & $8.93 \mathrm{CD}$ \\
\hline F. curculicola & PPRI 20464 & $14.08^{b c}$ & $14.61^{\mathrm{B}}$ \\
\hline Control & & $10.73^{c}$ & $5.82^{\mathrm{D}}$ \\
\hline
\end{tabular}

Least significant difference determined through Bonferroni $(\alpha=0.05)$ : Trial 1: $5.08^{(\mathrm{a}-\mathrm{c})}$; Trial 2: $3.61^{(\mathrm{A}-\mathrm{D})}$. Statistical difference between repeats one and two $(p<0.05)$; therefore, data were not combined. PPRI, National Collections of Fungi, Biosystematics Division, Plant Protection Research Council, Pretoria, South Africa. 


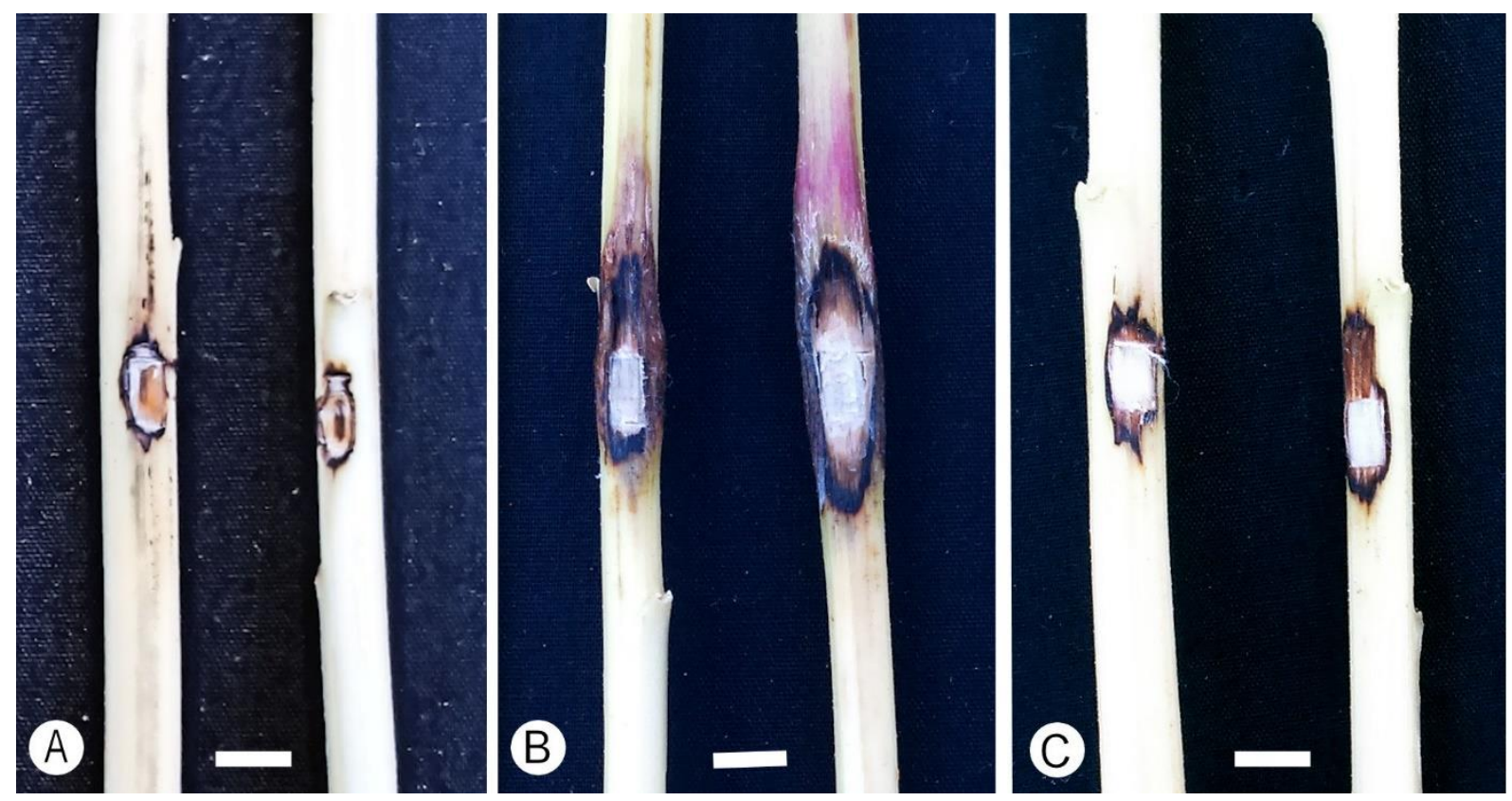

Figure 5. Lesions produced on Amaranthus cruentus in pathogenicity trials. (A) Control. (B) Inoculations with Fusarium casha (PPRI 21883). (C) Inoculation with F. curculicola (PPRI 20458). Bars: $5 \mathrm{~mm}$.

\section{Discussion}

This is the first study to identify Fusarium species occurring in Amaranthus species based on both phylogeny and morphology instead of only morphology. This approach led to the description of two novel species in the FFSC, one of which is a representative culture that was already isolated in 2004 from A. hybridus and misidentified as F. subglutinans at the time due to a lack of molecular data [23]. Both of these species showed the potential to be pathogenic to A. cruentus through routine pathogenicity techniques. These species should, therefore, be monitored due to their prominence and potential to cause disease in this crop.

Species in the FFSC are difficult to identify based solely on morphology due to the overall shortage of diagnostic morphological characters and the similarity of these characters between some species [14,15]. However, the two new species, F. curculicola and F. casha, have differentiating morphological characteristics from each other and from morphologically similar species. The microconidia of $F$. casha are quite variable, being oval, short clavate, ellipsoid, curved, c-shaped to obpyriform and arranged in false heads, while in F. curculicola, the microconidia are oval to obovoid, ellipsoid, short clavate, fusiform and arranged in false heads and long chains. Fusarium casha forms macroconidia that have distinctly notched basal cells and that are $0-5$ septate, while those of F. curculicola are 0-3 septate and shorter than those of F. casha. No chlamydospores were observed in both species. F. curculicola also formed intercalary phialides.

Interesting features of F. casha and F. curculicola are the occurrence of pleurophialides with phialidic openings on the surface of the running hyphae. The conventional phialides normally associated with Fusarium can then be referred to as orthophialides. These phialide morphologies were used in the sense of Gams [51]. It is unclear if other species in the FFSC have these characteristics since the morphology of conidiogenous cells forming macroconidia is poorly published overall. Such details are also usually not noted for microconidial conidiogenous cells. Species descriptions including such morphology $[3,5,7,8,52,53]$ together with descriptions from this study indicated that a conidiogenous cell morphology can prove diagnostic. For example, they indicated if conidiogenous cells are being formed in sporodochia or singly, whether they are found mingled with those bearing microconidia, whether phialides have different morphologies and the morphology of the conidiophore. Such details will enable more in-depth morphological identifications of species than what is currently possible. 
No sterile, coiled or circinate hyphae were observed for F. casha and F. curculicola. However, vegetative or running hyphae bearing conidiogenous cells often formed coiling circles consisting of numerous loops for both species. This can be confused with true circinate or coiled hyphae, as introduced for F. circinatum [49] and also present in F. pseudocircinatum, F. sterilihyphosum, F. parvisorum, F. mexicanum and F. tupiense as their diagnostic feature $[3,49,54-56]$. True circinate hyphae are thick, coiling, sterile and septate that can branch themselves and that are borne on running hyphae. The hyphal coilings of the running hyphae observed for F. casha and F. curcuricola are found in other Fusarium species, but their presence has not been noted well and is not known among the morphological characteristics usually considered when observing the morphology of FFSC species. Such a feature has, however, been noted in the recent species description of F. ficicrescens [13].

The present study increases our knowledge on the diversity and host range of the FFSC. The two novel species both group in the African clade of the FFSC. Based on the biogeographic hypotheses, the African, American and Asian clades in the FFSC are associated with the origin of the respective plant hosts from which the species of the FFSC were isolated [14]. The hosts of F. curculicola (A. cruentus) and F. casha (A. cruentus and $A$. hybridus) are, however, originally South American and not African. The lack of association can be ascribed to the fact that these two species have thus far not been found in South America and were introduced into Africa. Alternatively, these species are proposed to have an alternate native host in Africa and could then have the ability to infect $A$. cruentus and $A$. hybridus when these species were introduced to Africa. This is also possibly true for other species in the African clade. Fusarium coicis, F. verticillioides and F. musae, which are closely related to F. curculicola, have hosts that originate from Australia, Central America and Asia, respectively $[6,50,57]$. Fusarium volatile, also closely related to F. curculicola, is a human pathogen first described from a patient in French Guiana and not Africa [9]. Fusarium napiforme, F. ramigenum and F. tjaetaba are closely related to F. casha and have hosts that originate from Australia, the Middle East and Africa, respectively [6,9,49]. It is thus clear that the FFSC is under-represented in terms of reported host and geographical occurrences for species, and that more surveys on various hosts and in different geographic areas will possibly improve the phylogenetic resolution that will support or disprove the biogeographic origin hypothesis.

Not all isolates of F. casha and F. curcicola caused lesions in the pathogenicity trials on A. cruentus. These basic inoculations indicated that isolates of F. casha and F. curculicola have the potential to cause stem lesions, and that they could contribute to the disease symptoms originally observed in the field. However, more extensive pathogenicity trials may be needed to define this more closely, as indicated by the variation observed by some isolates in causing or not causing lesions. Furthermore, comparisons of F. casha and F. curcicola with Fusarium species shown not to cause disease symptoms on A. cruentus, or consistent lesions, will enable better comparisons.

Fusarium curculicola and F. casha were both isolated from weevils and their associated damage to amaranth. The presence of Fusarium species in association with weevil damage could either be due to the weevils vectoring the fungi, the fungi possibly serving as a food source or, alternatively, Fusarium species occurring as endophytes in amaranth and possibly being stimulated to become pathogenic due to the feeding activity of the weevils. This has been shown for a number of insect-associated Fusarium species [58]. Pathogenicity tests showed that both species newly described in this study have the potential to be pathogenic to A. cruentus without interaction with weevils. Further research is, however, needed to establish the role that these weevils and their feeding activity play in disease development caused by F. casha and F. curculicola in A. cruentus, and the type of association that exists between these fungi and the weevils. This study did not explore this further or attempt various inoculation techniques to study these interactions or the effect of the weevils alone. Such studies will have important implications for the control of both the weevils and their associated fungal pathogens should they be dependent on each other. 
Fusarium casha and F. curculicola were prevalent in A. cruentus stems. Together with damage caused by weevils in amaranth stems [22], this can prevent the movement of nutrients, resulting in reduced yield. Amaranthus cruentus currently planted in central South Africa is not clonal and, therefore, has genetic diversity that can account for variability in disease development. It is, therefore, important to consider F. casha and F. curculicola in future breeding and integrated pest management programs for $A$. cruentus. Since our study showed that $F$. casha can also infect another species, namely, $A$. hybridus, such programs most likely could be applied to other species and cultivars of Amaranthus.

Author Contributions: Research, results and writing, M.V.; statistical analyses, L.A.R.; supervision, W.J.S. and M.G.; editing and description, M.G. All authors have read and agreed to the published version of the manuscript.

Funding: Funding for this project was provided through the Cluster Programme of the University of the Free State.

\section{Institutional Review Board Statement: N/A.}

Data Availability Statement: Refer to Table 1.

Conflicts of Interest: The authors declare no conflict of interest. All the experiments undertaken in this study comply with the current laws of the country where they were performed.

\section{Appendix A}

Table A1. Isolates identified based on translation elongation factor $1 \alpha(\mathrm{TEF} 1 \alpha)$.

\begin{tabular}{|c|c|c|c|c|c|}
\hline Organism & Isolate & Host & Isolation Source & $\begin{array}{c}\text { TEF1 } \alpha \text { GenBank } \\
\text { Accession/ }\end{array}$ & Number of Isolates \\
\hline Fusarium casha & D22 & $\begin{array}{c}\text { Amaranthus } \\
\text { cruentus }\end{array}$ & $\begin{array}{l}\text { Emergence holes and lesions } \\
\text { associated with Athesapeuta dodonis } \\
\text { and Baris amaranti weevils }\end{array}$ & MN217126 & 1 \\
\hline Fusarium casha & D24 & $\begin{array}{c}\text { Amaranthus } \\
\text { cruentus }\end{array}$ & $\begin{array}{l}\text { Emergence holes and lesions } \\
\text { associated with Athesapeuta dodonis } \\
\text { and Baris amaranti weevils }\end{array}$ & MN217127 & 2 \\
\hline Fusarium casha & D21 & $\begin{array}{c}\text { Amaranthus } \\
\text { cruentus }\end{array}$ & $\begin{array}{l}\text { Emergence holes and lesions } \\
\text { associated with Athesapeuta dodonis } \\
\text { and Baris amaranti weevils }\end{array}$ & MN217130 & 3 \\
\hline Fusarium casha & D104 & $\begin{array}{l}\text { Amaranthus } \\
\text { cruentus }\end{array}$ & $\begin{array}{l}\text { Emergence holes and lesions } \\
\text { associated with Athesapeuta dodonis } \\
\text { and Baris amaranti weevils }\end{array}$ & MN217131 & 4 \\
\hline Fusarium casha & D118 & $\begin{array}{c}\text { Amaranthus } \\
\text { cruentus }\end{array}$ & $\begin{array}{l}\text { Emergence holes and lesions } \\
\text { associated with Athesapeuta dodonis } \\
\text { and Baris amaranti weevils }\end{array}$ & MN217132 & 5 \\
\hline Fusarium casha & D172 & $\begin{array}{c}\text { Amaranthus } \\
\text { cruentus }\end{array}$ & $\begin{array}{l}\text { Emergence holes and lesions } \\
\text { associated with Athesapeuta dodonis } \\
\text { and Baris amaranti weevils }\end{array}$ & MN217133 & 6 \\
\hline Fusarium casha & D179 & $\begin{array}{c}\text { Amaranthus } \\
\text { cruentus }\end{array}$ & $\begin{array}{l}\text { Emergence holes and lesions } \\
\text { associated with Athesapeuta dodonis } \\
\text { and Baris amaranti weevils }\end{array}$ & MN217138 & 7 \\
\hline Fusarium casha & D166 & $\begin{array}{c}\text { Amaranthus } \\
\text { cruentus }\end{array}$ & $\begin{array}{l}\text { Emergence holes and lesions } \\
\text { associated with Athesapeuta dodonis } \\
\text { and Baris amaranti weevils }\end{array}$ & MN217141 & 8 \\
\hline Fusarium casha & D4 & $\begin{array}{c}\text { Amaranthus } \\
\text { cruentus }\end{array}$ & $\begin{array}{l}\text { Emergence holes and lesions } \\
\text { associated with Athesapeuta dodonis } \\
\text { and Baris amaranti weevils }\end{array}$ & MN217143 & 9 \\
\hline
\end{tabular}


Table A1. Cont.

\begin{tabular}{|c|c|c|c|c|c|}
\hline Organism & Isolate & Host & Isolation Source & $\begin{array}{c}\text { TEF1 } \alpha \text { GenBank } \\
\text { Accession/ }\end{array}$ & Number of Isolates \\
\hline Fusarium casha & D140 & $\begin{array}{l}\text { Amaranthus } \\
\text { cruentus }\end{array}$ & $\begin{array}{l}\text { Emergence holes and lesions } \\
\text { associated with Athesapeuta dodonis } \\
\text { and Baris amaranti weevils }\end{array}$ & MN217145 & 10 \\
\hline Fusarium casha & D23 & $\begin{array}{l}\text { Amaranthus } \\
\text { cruentus }\end{array}$ & $\begin{array}{l}\text { Emergence holes and lesions } \\
\text { associated with Athesapeuta dodonis } \\
\text { and Baris amaranti weevils }\end{array}$ & MN217146 & 11 \\
\hline Fusarium casha & D28 & $\begin{array}{l}\text { Amaranthus } \\
\text { cruentus }\end{array}$ & $\begin{array}{l}\text { Emergence holes and lesions } \\
\text { associated with Athesapeuta dodonis } \\
\text { and Baris amaranti weevils }\end{array}$ & MN217148 & 12 \\
\hline Fusarium casha & D33 & $\begin{array}{c}\text { Amaranthus } \\
\text { cruentus }\end{array}$ & $\begin{array}{l}\text { Emergence holes and lesions } \\
\text { associated with Athesapeuta dodonis } \\
\text { and Baris amaranti weevils }\end{array}$ & MN217149 & 13 \\
\hline Fusarium casha & D183 & $\begin{array}{c}\text { Amaranthus } \\
\text { cruentus }\end{array}$ & $\begin{array}{l}\text { Emergence holes and lesions } \\
\text { associated with Athesapeuta dodonis } \\
\text { and Baris amaranti weevils }\end{array}$ & MN217150 & 14 \\
\hline Fusarium casha & D113 & $\begin{array}{l}\text { Amaranthus } \\
\text { cruentus }\end{array}$ & $\begin{array}{l}\text { Emergence holes and lesions } \\
\text { associated with Athesapeuta dodonis } \\
\text { and Baris amaranti weevils }\end{array}$ & MN217151 & 15 \\
\hline Fusarium casha & D32 & $\begin{array}{l}\text { Amaranthus } \\
\text { cruentus }\end{array}$ & $\begin{array}{l}\text { Emergence holes and lesions } \\
\text { associated with Athesapeuta dodonis } \\
\text { and Baris amaranti weevils }\end{array}$ & MN217152 & 16 \\
\hline Fusarium casha & D167 & $\begin{array}{l}\text { Amaranthus } \\
\text { cruentus }\end{array}$ & $\begin{array}{l}\text { Emergence holes and lesions } \\
\text { associated with Athesapeuta dodonis } \\
\text { and Baris amaranti weevils }\end{array}$ & MN217153 & 17 \\
\hline Fusarium casha & D39 & $\begin{array}{l}\text { Amaranthus } \\
\text { cruentus }\end{array}$ & $\begin{array}{l}\text { Emergence holes and lesions } \\
\text { associated with Athesapeuta dodonis } \\
\text { and Baris amaranti weevils }\end{array}$ & MN217159 & 18 \\
\hline Fusarium casha & D30 & $\begin{array}{l}\text { Amaranthus } \\
\text { cruentus }\end{array}$ & $\begin{array}{l}\text { Emergence holes and lesions } \\
\text { associated with Athesapeuta dodonis } \\
\text { and Baris amaranti weevils }\end{array}$ & MN217160 & 19 \\
\hline Fusarium casha & D111 & $\begin{array}{c}\text { Amaranthus } \\
\text { cruentus }\end{array}$ & $\begin{array}{l}\text { Emergence holes and lesions } \\
\text { associated with Athesapeuta dodonis } \\
\text { and Baris amaranti weevils }\end{array}$ & MN217161 & 20 \\
\hline Fusarium casha & D13 & $\begin{array}{c}\text { Amaranthus } \\
\text { cruentus }\end{array}$ & $\begin{array}{l}\text { Emergence holes and lesions } \\
\text { associated with Athesapeuta dodonis } \\
\text { and Baris amaranti weevils }\end{array}$ & MN217166 & 21 \\
\hline Fusarium casha & D5 & $\begin{array}{c}\text { Amaranthus } \\
\text { cruentus }\end{array}$ & $\begin{array}{l}\text { Emergence holes and lesions } \\
\text { associated with Athesapeuta dodonis } \\
\text { and Baris amaranti weevils }\end{array}$ & MN217167 & 22 \\
\hline Fusarium casha & D100 & $\begin{array}{l}\text { Amaranthus } \\
\text { cruentus }\end{array}$ & $\begin{array}{l}\text { Emergence holes and lesions } \\
\text { associated with Athesapeuta dodonis } \\
\text { and Baris amaranti weevils }\end{array}$ & MN217168 & 23 \\
\hline Fusarium casha & D112 & $\begin{array}{c}\text { Amaranthus } \\
\text { cruentus }\end{array}$ & $\begin{array}{l}\text { Emergence holes and lesions } \\
\text { associated with Athesapeuta dodonis } \\
\text { and Baris amaranti weevils }\end{array}$ & MN217175 & 24 \\
\hline Fusarium casha & D86 & $\begin{array}{l}\text { Amaranthus } \\
\text { cruentus }\end{array}$ & $\begin{array}{l}\text { Emergence holes and lesions } \\
\text { associated with Athesapeuta dodonis } \\
\text { and Baris amaranti weevils }\end{array}$ & MN217176 & 25 \\
\hline Fusarium casha & D119 & $\begin{array}{l}\text { Amaranthus } \\
\text { cruentus }\end{array}$ & $\begin{array}{l}\text { Emergence holes and lesions } \\
\text { associated with Athesapeuta dodonis } \\
\text { and Baris amaranti weevils }\end{array}$ & MN217177 & 26 \\
\hline
\end{tabular}


Table A1. Cont.

\begin{tabular}{|c|c|c|c|c|c|}
\hline Organism & Isolate & Host & Isolation Source & $\begin{array}{c}\text { TEF1 } \alpha \text { GenBank } \\
\text { Accession/ }\end{array}$ & Number of Isolates \\
\hline Fusarium casha & D110 & $\begin{array}{l}\text { Amaranthus } \\
\text { cruentus }\end{array}$ & $\begin{array}{l}\text { Emergence holes and lesions } \\
\text { associated with Athesapeuta dodonis } \\
\text { and Baris amaranti weevils }\end{array}$ & MN217178 & 27 \\
\hline Fusarium casha & D78 & $\begin{array}{l}\text { Amaranthus } \\
\text { cruentus }\end{array}$ & $\begin{array}{l}\text { Emergence holes and lesions } \\
\text { associated with Athesapeuta dodonis } \\
\text { and Baris amaranti weevils }\end{array}$ & MN217179 & 28 \\
\hline Fusarium casha & D203 & $\begin{array}{l}\text { Amaranthus } \\
\text { cruentus }\end{array}$ & $\begin{array}{l}\text { Emergence holes and lesions } \\
\text { associated with Athesapeuta dodonis } \\
\text { and Baris amaranti weevils }\end{array}$ & MN217181 & 29 \\
\hline Fusarium casha & D65 & $\begin{array}{c}\text { Amaranthus } \\
\text { cruentus }\end{array}$ & $\begin{array}{l}\text { Emergence holes and lesions } \\
\text { associated with Athesapeuta dodonis } \\
\text { and Baris amaranti weevils }\end{array}$ & MN217182 & 30 \\
\hline Fusarium casha & D76 & $\begin{array}{c}\text { Amaranthus } \\
\text { cruentus }\end{array}$ & $\begin{array}{l}\text { Emergence holes and lesions } \\
\text { associated with Athesapeuta dodonis } \\
\text { and Baris amaranti weevils }\end{array}$ & MN217183 & 31 \\
\hline Fusarium casha & D97 & $\begin{array}{c}\text { Amaranthus } \\
\text { cruentus }\end{array}$ & $\begin{array}{l}\text { Emergence holes and lesions } \\
\text { associated with Athesapeuta dodonis } \\
\text { and Baris amaranti weevils }\end{array}$ & MN217184 & 32 \\
\hline Fusarium casha & D99 & $\begin{array}{l}\text { Amaranthus } \\
\text { cruentus }\end{array}$ & $\begin{array}{l}\text { Emergence holes and lesions } \\
\text { associated with Athesapeuta dodonis } \\
\text { and Baris amaranti weevils }\end{array}$ & MN217186 & 33 \\
\hline Fusarium casha & D92 & $\begin{array}{c}\text { Amaranthus } \\
\text { cruentus }\end{array}$ & $\begin{array}{l}\text { Emergence holes and lesions } \\
\text { associated with Athesapeuta dodonis } \\
\text { and Baris amaranti weevils }\end{array}$ & MN217187 & 34 \\
\hline Fusarium casha & D164 & $\begin{array}{c}\text { Amaranthus } \\
\text { cruentus }\end{array}$ & $\begin{array}{l}\text { Emergence holes and lesions } \\
\text { associated with Athesapeuta dodonis } \\
\text { and Baris amaranti weevils }\end{array}$ & MN217189 & 35 \\
\hline Fusarium casha & D191 & $\begin{array}{c}\text { Amaranthus } \\
\text { cruentus }\end{array}$ & $\begin{array}{l}\text { Emergence holes and lesions } \\
\text { associated with Athesapeuta dodonis } \\
\text { and Baris amaranti weevils }\end{array}$ & MN217190 & 36 \\
\hline Fusarium casha & D187 & $\begin{array}{c}\text { Amaranthus } \\
\text { cruentus }\end{array}$ & $\begin{array}{l}\text { Emergence holes and lesions } \\
\text { associated with Athesapeuta dodonis } \\
\text { and Baris amaranti weevils }\end{array}$ & MN217195 & 37 \\
\hline Fusarium casha & D156 & $\begin{array}{c}\text { Amaranthus } \\
\text { cruentus }\end{array}$ & $\begin{array}{l}\text { Emergence holes and lesions } \\
\text { associated with Athesapeuta dodonis } \\
\text { and Baris amaranti weevils }\end{array}$ & MN217196 & 38 \\
\hline Fusarium casha & D200 & $\begin{array}{l}\text { Amaranthus } \\
\text { cruentus }\end{array}$ & $\begin{array}{l}\text { Emergence holes and lesions } \\
\text { associated with Athesapeuta dodonis } \\
\text { and Baris amaranti weevils }\end{array}$ & MN217201 & 39 \\
\hline Fusarium casha & D82 & $\begin{array}{l}\text { Amaranthus } \\
\text { cruentus }\end{array}$ & $\begin{array}{l}\text { Emergence holes and lesions } \\
\text { associated with Athesapeuta dodonis } \\
\text { and Baris amaranti weevils }\end{array}$ & MN217202 & 40 \\
\hline Fusarium casha & $32 B$ & $\begin{array}{c}\text { Amaranthus } \\
\text { cruentus }\end{array}$ & $\begin{array}{l}\text { Emergence holes and lesions } \\
\text { associated with Athesapeuta dodonis } \\
\text { and Baris amaranti weevils }\end{array}$ & MN217208 & 41 \\
\hline Fusarium casha & $27 \mathrm{~B}$ & $\begin{array}{c}\text { Amaranthus } \\
\text { cruentus }\end{array}$ & $\begin{array}{l}\text { Emergence holes and lesions } \\
\text { associated with Athesapeuta dodonis } \\
\text { and Baris amaranti weevils }\end{array}$ & MN217209 & 42 \\
\hline Fusarium casha & $\begin{array}{c}\text { PPRI } \\
\text { 21883/PREM } \\
61342\end{array}$ & $\begin{array}{l}\text { Amaranthus } \\
\text { cruentus }\end{array}$ & $\begin{array}{l}\text { Emergence holes and lesions } \\
\text { associated with Athesapeuta dodonis } \\
\text { and Baris amaranti weevils }\end{array}$ & MF787261 & 43 \\
\hline
\end{tabular}


Table A1. Cont.

\begin{tabular}{|c|c|c|c|c|c|}
\hline Organism & Isolate & Host & Isolation Source & $\begin{array}{c}\text { TEF1 } \alpha \text { GenBank } \\
\text { Accession/ }\end{array}$ & Number of Isolates \\
\hline $\begin{array}{l}\text { Fusarium } \\
\text { casha }\end{array}$ & & $\begin{array}{c}\text { Amaranthus } \\
\text { cruentus }\end{array}$ & $\begin{array}{l}\text { Emergence holes and lesions } \\
\text { associated with Athesapeuta } \\
\text { dodonis and Baris amaranti } \\
\text { weevils }\end{array}$ & Subtotal & 43 \\
\hline $\begin{array}{l}\text { Fusarium } \\
\text { curculicola }\end{array}$ & D175 & $\begin{array}{l}\text { Amaranthus } \\
\text { cruentus }\end{array}$ & $\begin{array}{l}\text { Emergence holes and lesions } \\
\text { associated with Athesapeuta dodonis } \\
\text { and Baris amaranti weevils }\end{array}$ & MN202618 & 1 \\
\hline $\begin{array}{l}\text { Fusarium } \\
\text { curculicola }\end{array}$ & D74 & $\begin{array}{l}\text { Amaranthus } \\
\text { cruentus }\end{array}$ & $\begin{array}{l}\text { Emergence holes and lesions } \\
\text { associated with Athesapeuta dodonis } \\
\text { and Baris amaranti weevils }\end{array}$ & MN202619 & 2 \\
\hline $\begin{array}{l}\text { Fusarium } \\
\text { curculicola }\end{array}$ & D10 & $\begin{array}{l}\text { Amaranthus } \\
\text { cruentus }\end{array}$ & $\begin{array}{l}\text { Emergence holes and lesions } \\
\text { associated with Athesapeuta dodonis } \\
\text { and Baris amaranti weevils }\end{array}$ & MN202621 & 3 \\
\hline $\begin{array}{l}\text { Fusarium } \\
\text { curculicola }\end{array}$ & D12 & $\begin{array}{l}\text { Amaranthus } \\
\text { cruentus }\end{array}$ & $\begin{array}{l}\text { Emergence holes and lesions } \\
\text { associated with Athesapeuta dodonis } \\
\text { and Baris amaranti weevils }\end{array}$ & MN202622 & 4 \\
\hline $\begin{array}{l}\text { Fusarium } \\
\text { curculicola }\end{array}$ & D129 & $\begin{array}{l}\text { Amaranthus } \\
\text { cruentus }\end{array}$ & $\begin{array}{l}\text { Emergence holes and lesions } \\
\text { associated with Athesapeuta dodonis } \\
\text { and Baris amaranti weevils }\end{array}$ & MN202624 & 5 \\
\hline $\begin{array}{l}\text { Fusarium } \\
\text { curculicola }\end{array}$ & D199 & $\begin{array}{c}\text { Amaranthus } \\
\text { cruentus }\end{array}$ & $\begin{array}{l}\text { Emergence holes and lesions } \\
\text { associated with Athesapeuta dodonis } \\
\text { and Baris amaranti weevils }\end{array}$ & MN202627 & 6 \\
\hline $\begin{array}{l}\text { Fusarium } \\
\text { curculicola }\end{array}$ & D176 & $\begin{array}{c}\text { Amaranthus } \\
\text { cruentus }\end{array}$ & $\begin{array}{l}\text { Emergence holes and lesions } \\
\text { associated with Athesapeuta dodonis } \\
\text { and Baris amaranti weevils }\end{array}$ & MN202629 & 7 \\
\hline $\begin{array}{l}\text { Fusarium } \\
\text { curculicola }\end{array}$ & D14 & $\begin{array}{c}\text { Amaranthus } \\
\text { cruentus }\end{array}$ & $\begin{array}{l}\text { Emergence holes and lesions } \\
\text { associated with Athesapeuta dodonis } \\
\text { and Baris amaranti weevils }\end{array}$ & MN202630 & 8 \\
\hline $\begin{array}{l}\text { Fusarium } \\
\text { curculicola }\end{array}$ & D154 & $\begin{array}{c}\text { Amaranthus } \\
\text { cruentus }\end{array}$ & $\begin{array}{l}\text { Emergence holes and lesions } \\
\text { associated with Athesapeuta dodonis } \\
\text { and Baris amaranti weevils }\end{array}$ & MN202632 & 9 \\
\hline $\begin{array}{l}\text { Fusarium } \\
\text { curculicola }\end{array}$ & D6 & $\begin{array}{c}\text { Amaranthus } \\
\text { cruentus }\end{array}$ & $\begin{array}{l}\text { Emergence holes and lesions } \\
\text { associated with Athesapeuta dodonis } \\
\text { and Baris amaranti weevils }\end{array}$ & MN202635 & 10 \\
\hline $\begin{array}{l}\text { Fusarium } \\
\text { curculicola }\end{array}$ & D91 & $\begin{array}{c}\text { Amaranthus } \\
\text { cruentus }\end{array}$ & $\begin{array}{l}\text { Emergence holes and lesions } \\
\text { associated with Athesapeuta dodonis } \\
\text { and Baris amaranti weevils }\end{array}$ & MN202636 & 11 \\
\hline $\begin{array}{l}\text { Fusarium } \\
\text { curculicola }\end{array}$ & D115 & $\begin{array}{c}\text { Amaranthus } \\
\text { cruentus }\end{array}$ & $\begin{array}{l}\text { Emergence holes and lesions } \\
\text { associated with Athesapeuta dodonis } \\
\text { and Baris amaranti weevils }\end{array}$ & MN202643 & 12 \\
\hline $\begin{array}{l}\text { Fusarium } \\
\text { curculicola }\end{array}$ & D107 & $\begin{array}{c}\text { Amaranthus } \\
\text { cruentus }\end{array}$ & $\begin{array}{l}\text { Emergence holes and lesions } \\
\text { associated with Athesapeuta dodonis } \\
\text { and Baris amaranti weevils }\end{array}$ & MN202644 & 13 \\
\hline $\begin{array}{l}\text { Fusarium } \\
\text { curculicola }\end{array}$ & D106 & $\begin{array}{c}\text { Amaranthus } \\
\text { cruentus }\end{array}$ & $\begin{array}{l}\text { Emergence holes and lesions } \\
\text { associated with Athesapeuta dodonis } \\
\text { and Baris amaranti weevils }\end{array}$ & MN202645 & 14 \\
\hline $\begin{array}{l}\text { Fusarium } \\
\text { curculicola }\end{array}$ & D102 & $\begin{array}{c}\text { Amaranthus } \\
\text { cruentus }\end{array}$ & $\begin{array}{l}\text { Emergence holes and lesions } \\
\text { associated with Athesapeuta dodonis } \\
\text { and Baris amaranti weevils }\end{array}$ & MN202646 & 15 \\
\hline $\begin{array}{l}\text { Fusarium } \\
\text { curculicola }\end{array}$ & D98 & $\begin{array}{l}\text { Amaranthus } \\
\text { cruentus }\end{array}$ & $\begin{array}{l}\text { Emergence holes and lesions } \\
\text { associated with Athesapeuta dodonis } \\
\text { and Baris amaranti weevils }\end{array}$ & MN202647 & 16 \\
\hline
\end{tabular}


Table A1. Cont.

\begin{tabular}{|c|c|c|c|c|c|}
\hline Organism & Isolate & Host & Isolation Source & $\begin{array}{c}\text { TEF1 } \alpha \text { GenBank } \\
\text { Accession/ }\end{array}$ & Number of Isolates \\
\hline $\begin{array}{l}\text { Fusarium } \\
\text { curculicola }\end{array}$ & D67 & $\begin{array}{c}\text { Amaranthus } \\
\text { cruentus }\end{array}$ & $\begin{array}{l}\text { Emergence holes and lesions } \\
\text { associated with Athesapeuta dodonis } \\
\text { and Baris amaranti weevils }\end{array}$ & MN202648 & 17 \\
\hline $\begin{array}{l}\text { Fusarium } \\
\text { curculicola }\end{array}$ & D36 & $\begin{array}{c}\text { Amaranthus } \\
\text { cruentus }\end{array}$ & $\begin{array}{l}\text { Emergence holes and lesions } \\
\text { associated with Athesapeuta dodonis } \\
\text { and Baris amaranti weevils }\end{array}$ & MN202649 & 18 \\
\hline $\begin{array}{l}\text { Fusarium } \\
\text { curculicola }\end{array}$ & $14 \mathrm{~A}$ & $\begin{array}{c}\text { Amaranthus } \\
\text { cruentus }\end{array}$ & $\begin{array}{l}\text { Emergence holes and lesions } \\
\text { associated with Athesapeuta dodonis } \\
\text { and Baris amaranti weevils }\end{array}$ & MN202653 & 19 \\
\hline $\begin{array}{l}\text { Fusarium } \\
\text { curculicola }\end{array}$ & D103 & $\begin{array}{c}\text { Amaranthus } \\
\text { cruentus }\end{array}$ & $\begin{array}{l}\text { Emergence holes and lesions } \\
\text { associated with Athesapeuta dodonis } \\
\text { and Baris amaranti weevils }\end{array}$ & MN202654 & 20 \\
\hline $\begin{array}{l}\text { Fusarium } \\
\text { curculicola }\end{array}$ & D88 & $\begin{array}{c}\text { Amaranthus } \\
\text { cruentus }\end{array}$ & $\begin{array}{l}\text { Emergence holes and lesions } \\
\text { associated with Athesapeuta dodonis } \\
\text { and Baris amaranti weevils }\end{array}$ & MN202656 & 21 \\
\hline $\begin{array}{l}\text { Fusarium } \\
\text { curculicola }\end{array}$ & D87 & $\begin{array}{c}\text { Amaranthus } \\
\text { cruentus }\end{array}$ & $\begin{array}{l}\text { Emergence holes and lesions } \\
\text { associated with Athesapeuta dodonis } \\
\text { and Baris amaranti weevils }\end{array}$ & MN202657 & 22 \\
\hline $\begin{array}{l}\text { Fusarium } \\
\text { curculicola }\end{array}$ & $\begin{array}{l}\text { PPRI } \\
\text { 20386/PREM } \\
61347 \\
\end{array}$ & $\begin{array}{l}\text { Amaranthus } \\
\text { cruentus }\end{array}$ & $\begin{array}{l}\text { Emergence holes and lesions } \\
\text { associated with Athesapeuta dodonis } \\
\text { and Baris amaranti weevils }\end{array}$ & MF787268 & 23 \\
\hline \multirow[t]{2}{*}{$\begin{array}{l}\text { Fusarium } \\
\text { curculicola }\end{array}$} & & $\begin{array}{c}\text { Amaranthus } \\
\text { cruentus }\end{array}$ & $\begin{array}{l}\text { Emergence holes and lesions } \\
\text { associated with Athesapeuta } \\
\text { dodonis and Baris amaranti } \\
\text { weevils }\end{array}$ & Subtotal & 23 \\
\hline & & $\begin{array}{c}\text { Amaranthus } \\
\text { cruentus }\end{array}$ & $\begin{array}{l}\text { Emergence holes and lesions } \\
\text { associated with Athesapeuta } \\
\text { dodonis and Baris amaranti } \\
\text { weevils }\end{array}$ & Total & 66 \\
\hline Fusarium casha & D216 & $\begin{array}{c}\text { Amaranthus } \\
\text { cruentus }\end{array}$ & Larval gallery of Hypolixus haerens & MN217142 & 1 \\
\hline Fusarium casha & D144 & $\begin{array}{c}\text { Amaranthus } \\
\text { cruentus }\end{array}$ & Larval gallery of Hypolixus haerens & MN217144 & 2 \\
\hline Fusarium casha & D128 & $\begin{array}{c}\text { Amaranthus } \\
\text { cruentus }\end{array}$ & Larval gallery of Hypolixus haerens & MN217147 & 3 \\
\hline Fusarium casha & D158 & $\begin{array}{c}\text { Amaranthus } \\
\text { cruentus }\end{array}$ & Larval gallery of Hypolixus haerens & MN217158 & 4 \\
\hline Fusarium casha & D57 & $\begin{array}{c}\text { Amaranthus } \\
\text { cruentus }\end{array}$ & Larval gallery of Hypolixus haerens & MN217171 & 5 \\
\hline Fusarium casha & D81 & $\begin{array}{c}\text { Amaranthus } \\
\text { cruentus }\end{array}$ & Larval gallery of Hypolixus haerens & MN217172 & 6 \\
\hline Fusarium casha & D62 & $\begin{array}{c}\text { Amaranthus } \\
\text { cruentus }\end{array}$ & Larval gallery of Hypolixus haerens & MN217173 & 7 \\
\hline Fusarium casha & D59 & $\begin{array}{c}\text { Amaranthus } \\
\text { cruentus }\end{array}$ & Larval gallery of Hypolixus haerens & MN217174 & 8 \\
\hline Fusarium casha & D209 & $\begin{array}{c}\text { Amaranthus } \\
\text { cruentus }\end{array}$ & Larval gallery of Hypolixus haerens & MN217199 & 9 \\
\hline Fusarium casha & D121 & $\begin{array}{c}\text { Amaranthus } \\
\text { cruentus }\end{array}$ & Larval gallery of Hypolixus haerens & MN217200 & 10 \\
\hline $\begin{array}{l}\text { Fusarium } \\
\text { casha }\end{array}$ & & $\begin{array}{l}\text { Amaranthus } \\
\text { cruentus }\end{array}$ & $\begin{array}{l}\text { Larval gallery of Hypolixus } \\
\text { haerens }\end{array}$ & Subtotal & 10 \\
\hline
\end{tabular}


Table A1. Cont.

\begin{tabular}{|c|c|c|c|c|c|}
\hline Organism & Isolate & Host & Isolation Source & $\begin{array}{c}\text { TEF1 } \alpha \text { GenBank } \\
\text { Accession/ }\end{array}$ & Number of Isolates \\
\hline $\begin{array}{l}\text { Fusarium } \\
\text { curculicola }\end{array}$ & D131 & $\begin{array}{l}\text { Amaranthus } \\
\text { cruentus }\end{array}$ & Larval gallery of Hypolixus haerens & MN202617 & 1 \\
\hline $\begin{array}{c}\text { Fusarium } \\
\text { curculicola }\end{array}$ & D68 & $\begin{array}{c}\text { Amaranthus } \\
\text { cruentus }\end{array}$ & Larval gallery of Hypolixus haerens & MN202650 & 2 \\
\hline $\begin{array}{c}\text { Fusarium } \\
\text { curculicola }\end{array}$ & & $\begin{array}{l}\text { Amaranthus } \\
\text { cruentus }\end{array}$ & $\begin{array}{l}\text { Larval gallery of Hypolixus } \\
\text { haerens }\end{array}$ & Subtotal & 2 \\
\hline $\begin{array}{l}\text { Fusarium } \\
\text { curculicola }\end{array}$ & & $\begin{array}{l}\text { Amaranthus } \\
\text { cruentus }\end{array}$ & $\begin{array}{l}\text { Larval gallery of Hypolixus } \\
\text { haerens }\end{array}$ & Total & 12 \\
\hline Fusarium casha & JB341FS & $\begin{array}{l}\text { Amaranthus } \\
\text { hybridus }\end{array}$ & $\begin{array}{l}\text { Cankered stems of Amaranthus } \\
\text { hybridus }\end{array}$ & MN217170 & 1 \\
\hline $\begin{array}{l}\text { Fusarium } \\
\text { casha }\end{array}$ & & $\begin{array}{l}\text { Amaranthus } \\
\text { hybridus }\end{array}$ & $\begin{array}{l}\text { Cankered stems of Amaranthus } \\
\text { hybridus }\end{array}$ & Subtotal & 1 \\
\hline Fusarium casha & JB143FS & $\begin{array}{l}\text { Amaranthus } \\
\text { hybridus }\end{array}$ & Larval gallery of Hypolixus haerens & MF787264 & 1 \\
\hline $\begin{array}{l}\text { Fusarium } \\
\text { casha }\end{array}$ & & $\begin{array}{l}\text { Amaranthus } \\
\text { hybridus }\end{array}$ & $\begin{array}{l}\text { Larval gallery of Hypolixus } \\
\text { haerens }\end{array}$ & Subtotal & 1 \\
\hline Fusarium casha & $\mathrm{T} 82 \mathrm{~B}$ & $\begin{array}{l}\text { Athesapeuta } \\
\text { dodonis }\end{array}$ & & MN217125 & 1 \\
\hline Fusarium casha & P148 & $\begin{array}{l}\text { Athesapeuta } \\
\text { dodonis }\end{array}$ & & MN217134 & 2 \\
\hline Fusarium casha & $\mathrm{T} 22 \mathrm{~A}$ & $\begin{array}{l}\text { Athesapeuta } \\
\text { dodonis }\end{array}$ & & MN217136 & 3 \\
\hline Fusarium casha & P91A & $\begin{array}{l}\text { Athesapeuta } \\
\text { dodonis }\end{array}$ & & MN217137 & 4 \\
\hline Fusarium casha & $\mathrm{T} 73 \mathrm{~A}$ & $\begin{array}{l}\text { Athesapeuta } \\
\text { dodonis }\end{array}$ & & MN217139 & 5 \\
\hline Fusarium casha & P147A & $\begin{array}{l}\text { Athesapeuta } \\
\text { dodonis }\end{array}$ & & MN217154 & 6 \\
\hline Fusarium casha & P70 & $\begin{array}{l}\text { Athesapeuta } \\
\text { dodonis }\end{array}$ & & MN217162 & 7 \\
\hline Fusarium casha & P145A & $\begin{array}{l}\text { Athesapeuta } \\
\text { dodonis }\end{array}$ & & MN217163 & 8 \\
\hline Fusarium casha & $\mathrm{T} 62 \mathrm{~A}$ & $\begin{array}{l}\text { Athesapeuta } \\
\text { dodonis }\end{array}$ & & MN217164 & 9 \\
\hline Fusarium casha & P133A & $\begin{array}{l}\text { Athesapeuta } \\
\text { dodonis }\end{array}$ & & MN217165 & 10 \\
\hline Fusarium casha & T142A & $\begin{array}{l}\text { Athesapeuta } \\
\text { dodonis }\end{array}$ & & MN217169 & 11 \\
\hline Fusarium casha & P143A & $\begin{array}{l}\text { Athesapeuta } \\
\text { dodonis }\end{array}$ & & MN217180 & 12 \\
\hline Fusarium casha & T27B & $\begin{array}{l}\text { Athesapeuta } \\
\text { dodonis }\end{array}$ & & MN217185 & 13 \\
\hline Fusarium casha & P97A & $\begin{array}{c}\text { Athesapeuta } \\
\text { dodonis }\end{array}$ & & MN217191 & 14 \\
\hline Fusarium casha & $\mathrm{T} 20 \mathrm{~A}$ & $\begin{array}{c}\text { Athesapeuta } \\
\text { dodonis }\end{array}$ & & MN217192 & 15 \\
\hline Fusarium casha & P26A & $\begin{array}{c}\text { Athesapeuta } \\
\text { dodonis }\end{array}$ & & MN217193 & 16 \\
\hline Fusarium casha & T49A & $\begin{array}{c}\text { Athesapeuta } \\
\text { dodonis }\end{array}$ & & MN217194 & 17 \\
\hline
\end{tabular}


Table A1. Cont.

\begin{tabular}{|c|c|c|c|c|c|}
\hline Organism & Isolate & Host & Isolation Source & $\begin{array}{c}\text { TEF1 } \alpha \text { GenBank } \\
\text { Accession/ }\end{array}$ & Number of Isolates \\
\hline Fusarium casha & P65B & $\begin{array}{c}\text { Athesapeuta } \\
\text { dodonis }\end{array}$ & & MN217197 & 18 \\
\hline Fusarium casha & $\mathrm{T} 41 \mathrm{~A}$ & $\begin{array}{c}\text { Athesapeuta } \\
\text { dodonis }\end{array}$ & & MN217198 & 19 \\
\hline Fusarium casha & $\mathrm{T} 56 \mathrm{~A}$ & $\begin{array}{c}\text { Athesapeuta } \\
\text { dodonis }\end{array}$ & & MN217203 & 20 \\
\hline Fusarium casha & T71A & $\begin{array}{c}\text { Athesapeuta } \\
\text { dodonis }\end{array}$ & & MN217204 & 21 \\
\hline Fusarium casha & T31A & $\begin{array}{c}\text { Athesapeuta } \\
\text { dodonis }\end{array}$ & & MN217205 & 22 \\
\hline Fusarium casha & P69A & $\begin{array}{c}\text { Athesapeuta } \\
\text { dodonis }\end{array}$ & & MN217206 & 23 \\
\hline Fusarium casha & P37A & $\begin{array}{c}\text { Athesapeuta } \\
\text { dodonis }\end{array}$ & & MN217207 & 24 \\
\hline Fusarium casha & P135A & $\begin{array}{c}\text { Athesapeuta } \\
\text { dodonis }\end{array}$ & & MN217210 & 25 \\
\hline Fusarium casha & P117B & $\begin{array}{c}\text { Athesapeuta } \\
\text { dodonis }\end{array}$ & & MN217211 & 26 \\
\hline Fusarium casha & $\mathrm{T} 28 \mathrm{~A}$ & $\begin{array}{c}\text { Athesapeuta } \\
\text { dodonis }\end{array}$ & & MN217212 & 27 \\
\hline Fusarium casha & P63A & $\begin{array}{c}\text { Athesapeuta } \\
\text { dodonis }\end{array}$ & & MN217213 & 28 \\
\hline Fusarium casha & T137B & $\begin{array}{c}\text { Athesapeuta } \\
\text { dodonis }\end{array}$ & & MN217214 & 29 \\
\hline Fusarium casha & $\begin{array}{c}\text { PPRI } \\
\text { 20462/PREM } \\
61343\end{array}$ & $\begin{array}{c}\text { Athesapeuta } \\
\text { dodonis }\end{array}$ & & MF787262 & 30 \\
\hline Fusarium casha & $\begin{array}{c}\text { PPRI } \\
\text { 20468/PREM } \\
61344 \\
\end{array}$ & $\begin{array}{c}\text { Athesapeuta } \\
\text { dodonis }\end{array}$ & & MF787263 & 31 \\
\hline $\begin{array}{c}\text { Fusarium } \\
\text { casha }\end{array}$ & & $\begin{array}{c}\text { Athesapeuta } \\
\text { dodonis }\end{array}$ & & Total & 31 \\
\hline $\begin{array}{l}\text { Fusarium } \\
\text { curculicola }\end{array}$ & P120B & $\begin{array}{c}\text { Athesapeuta } \\
\text { dodonis }\end{array}$ & & MN202631 & 1 \\
\hline $\begin{array}{l}\text { Fusarium } \\
\text { curculicola }\end{array}$ & T150B & $\begin{array}{c}\text { Athesapeuta } \\
\text { dodonis }\end{array}$ & & MN202634 & 2 \\
\hline $\begin{array}{l}\text { Fusarium } \\
\text { curculicola }\end{array}$ & $\mathrm{T} 113$ & $\begin{array}{c}\text { Athesapeuta } \\
\text { dodonis }\end{array}$ & & MN202638 & 3 \\
\hline $\begin{array}{l}\text { Fusarium } \\
\text { curculicola }\end{array}$ & T66 & $\begin{array}{c}\text { Athesapeuta } \\
\text { dodonis }\end{array}$ & & MN202639 & 4 \\
\hline $\begin{array}{l}\text { Fusarium } \\
\text { curculicola }\end{array}$ & $\mathrm{T} 11$ & $\begin{array}{c}\text { Athesapeuta } \\
\text { dodonis }\end{array}$ & & MN202640 & 5 \\
\hline $\begin{array}{l}\text { Fusarium } \\
\text { curculicola }\end{array}$ & P92B & $\begin{array}{c}\text { Athesapeuta } \\
\text { dodonis }\end{array}$ & & MN202641 & 6 \\
\hline $\begin{array}{l}\text { Fusarium } \\
\text { curculicola }\end{array}$ & P141B & $\begin{array}{c}\text { Athesapeuta } \\
\text { dodonis }\end{array}$ & & MN202642 & 7 \\
\hline $\begin{array}{l}\text { Fusarium } \\
\text { curculicola }\end{array}$ & T97A & $\begin{array}{c}\text { Athesapeuta } \\
\text { dodonis }\end{array}$ & & MN202651 & 8 \\
\hline $\begin{array}{l}\text { Fusarium } \\
\text { curculicola }\end{array}$ & $\mathrm{T} 43$ & $\begin{array}{c}\text { Athesapeuta } \\
\text { dodonis }\end{array}$ & & MN202652 & 9 \\
\hline
\end{tabular}


Table A1. Cont.

\begin{tabular}{|c|c|c|c|c|c|}
\hline Organism & Isolate & Host & Isolation Source & $\begin{array}{c}\text { TEF1 } \alpha \text { GenBank } \\
\text { Accession/ }\end{array}$ & Number of Isolates \\
\hline $\begin{array}{l}\text { Fusarium } \\
\text { curculicola }\end{array}$ & T90A & $\begin{array}{c}\text { Athesapeuta } \\
\text { dodonis }\end{array}$ & & MN202658 & 10 \\
\hline $\begin{array}{l}\text { Fusarium } \\
\text { curculicola }\end{array}$ & $\begin{array}{c}\text { PPRI } \\
20458 / \text { PREM } \\
61345\end{array}$ & $\begin{array}{c}\text { Athesapeuta } \\
\text { dodonis }\end{array}$ & & MF787266 & 11 \\
\hline $\begin{array}{l}\text { Fusarium } \\
\text { curculicola }\end{array}$ & $\begin{array}{c}\text { PPRI } \\
\text { 20464/PREM } \\
61346 \\
\end{array}$ & $\begin{array}{c}\text { Athesapeuta } \\
\text { dodonis }\end{array}$ & & MF787267 & 12 \\
\hline \multirow[t]{2}{*}{$\begin{array}{c}\text { Fusarium } \\
\text { curculicola }\end{array}$} & & $\begin{array}{l}\text { Athesapeuta } \\
\text { dodonis }\end{array}$ & & Subtotal & 12 \\
\hline & & $\begin{array}{c}\text { Athesapeuta } \\
\text { dodonis }\end{array}$ & & Total & 43 \\
\hline Fusarium casha & D206 & $\begin{array}{c}\text { Baris } \\
\text { amaranti }\end{array}$ & & MN217129 & 1 \\
\hline Fusarium casha & D157 & $\begin{array}{c}\text { Baris } \\
\text { amaranti }\end{array}$ & & MN217155 & 2 \\
\hline $\begin{array}{c}\text { Fusarium } \\
\text { casha }\end{array}$ & & $\begin{array}{c}\text { Baris } \\
\text { amaranti }\end{array}$ & & Subtotal & 2 \\
\hline $\begin{array}{l}\text { Fusarium } \\
\text { curculicola }\end{array}$ & P88A & $\begin{array}{c}\text { Baris } \\
\text { amaranti }\end{array}$ & & MN202625 & 1 \\
\hline \multirow[t]{2}{*}{$\begin{array}{c}\text { Fusarium } \\
\text { curculicola }\end{array}$} & & $\begin{array}{c}\text { Baris } \\
\text { amaranti }\end{array}$ & & Subtotal & 1 \\
\hline & & $\begin{array}{c}\text { Baris } \\
\text { amaranti }\end{array}$ & & Total & 3 \\
\hline Fusarium casha & D152 & $\begin{array}{l}\text { Larvae of } \\
\text { Hypolixus } \\
\text { haerens }\end{array}$ & & MN217157 & 1 \\
\hline Fusarium casha & D218 & $\begin{array}{l}\text { Larvae of } \\
\text { Hypolixus } \\
\text { haerens }\end{array}$ & & MN217188 & 2 \\
\hline $\begin{array}{l}\text { Fusarium } \\
\text { casha }\end{array}$ & & $\begin{array}{c}\text { Larvae of } \\
\text { Hypolixus } \\
\text { haerens }\end{array}$ & & Subtotal & 2 \\
\hline $\begin{array}{l}\text { Fusarium } \\
\text { curculicola }\end{array}$ & D37 & $\begin{array}{l}\text { Larvae of } \\
\text { Hypolixus } \\
\text { haerens }\end{array}$ & & MN202637 & 1 \\
\hline \multirow[t]{3}{*}{$\begin{array}{c}\text { Fusarium } \\
\text { curculicola }\end{array}$} & & $\begin{array}{c}\text { Larvae of } \\
\text { Hypolixus } \\
\text { haerens }\end{array}$ & & Subtotal & 1 \\
\hline & & $\begin{array}{l}\text { Larvae of } \\
\text { Hypolixus } \\
\text { haerens }\end{array}$ & & Subtotal & 3 \\
\hline & & & & Sum total & 129 \\
\hline
\end{tabular}

\section{References}

1. Pusz, W. Fungi from seeds of Amaranthus spp. Phytopathologia 2009, 54, 15-21.

2. Walsh, J.L.; Laurence, M.H.; Liew, E.C.Y.; Sangalang, A.E.; Burgess, L.W.; Summerell, B.A.; Petrovic, T. Fusarium: Two endophytic novel species from tropical grasses of northern Australia. Fungal Divers. 2010, 44, 149-159. [CrossRef]

3. Herron, D.A.; Wingfield, M.J.; Wingfield, B.D.; Rodas, C.A.; Marincowitz, S.; Steenkamp, E.T. Novel taxa in the Fusarium fujikuroi species complex from Pinus spp. Stud. Mycol. 2015, 80, 131-150. [CrossRef] [PubMed] 
4. Al-Hatmi, A.M.S.; Mirabolfathy, M.; Hagen, F.; Normand, A.C.; Stielow, B.; Karami-Osbo, R.; van Diepeningen, A.D.; Meis, J.F.; De Hoog, S. DNA barcoding, MALDI-TOF, and AFLP data support Fusarium ficicrescens as a distinct species within the Fusarium fujikuroi species complex. Fungal Biol. 2016, 120, 265-278. [CrossRef] [PubMed]

5. Edwards, J.; Auer, D.; de Alwis, S.-K.; Summerell, B.; Aoki, T.; Proctor, R.H.; Busmann, M.; O’Donnell, K. Fusarium agapanthi sp. nov., a novel bikaverin and fusarubin-producing leaf and stem spot pathogen of Agapanthus praecox (African lily) from Australia and Italy. Mycologia 2016, 108, 981-992. [CrossRef]

6. $\quad$ Laurence, M.H.; Walsh, L.A.; Shuttleworth, L.A.; Robinson, D.M.; Johansen, R.M.; Petrovic, T.; Vu, T.T.H.; Burgess, L.W.; Summerell, B.A.; Liew, E.C.Y. Six novel species of Fusarium from natural ecosystems in Australia. Fungal Divers. 2016, 77, 349-366. [CrossRef]

7. Moussa, T.A.A.; Al-Zahrani, H.S.; Kadasa, N.M.S.; Ahmed, S.A.; De Hoog, G.S.; Al-Hatmi, A.M.S. Two new species of the Fusarium fujikuroi species complex isolated from the natural environment. Antonie Van Leeuwenhoek 2017, 110, 819-832. [CrossRef]

8. Sandoval-Denis, M.; Swart, W.J.; Crous, P.W. New Fusarium species from the Kruger National Park, South Africa. MycoKeys 2018, 34, 63-92. [CrossRef] [PubMed]

9. Al-Hatmi, A.M.S.; Sandoval-Denis, M.; Nabet, C.; Ahmed, S.A.; Demar, M.; Normand, A.-C.; De Hoog, G.S. Fusarium volatile, a new pathogen from human respiratory samples. Fungal Syst. Evol. 2019, 4, 171-181. [CrossRef]

10. Leslie, J.F.; Summerell, B.A. The Fusarium Laboratory Manual; Blackwell Professional: Ames, IA, USA, 2006.

11. Kvas, M.; Marasas, W.F.O.; Wingfield, B.D.; Wingfield, M.J.; Steenkamp, E.T. Diversity and evolution of Fusarium species in the Gibberella fujikuroi complex. Fungal Divers. 2009, 34, 1-21.

12. Proctor, R.H.; Van Hove, F.; Susca, A.; Stea, G.; Busman, M.; van der Lee, T.; Waalwijk, C.; Moretti, A.; Ward, T.J. Birth, death and horizontal transfer of the fumonisin biosynthetic gene cluster during the evolutionary diversification of Fusarium. Mol. Microbiol. 2013, 90, 290-306.

13. Al-Hatmi, A.M.S.; Van Den Ende, A.H.G.; Stielow, B.; Van Diepeningen, A.D.; Seifert, K.A.; Mccormick, W.; Assabgui, R.; Gräfenhan, T.; De Hoog, G.S.; Levesque, C.A. Evaluation of two novel barcodes for species recognition of opportunistic pathogens in Fusarium. Fungal Biol. 2015, 120, 231-245. [CrossRef] [PubMed]

14. O'Donnell, K.; Cigelnik, E.; Nirenberg, H.I. Molecular systematics and phylogeography of the Gibberella fujikuroi species complex. Mycologia 1998, 90, 465-493. [CrossRef]

15. O'Donnell, K.; Nirenberg, H.I.; Aoki, T.; Cigelnik, E. A multigene phylogeny of the Gibberella fujikuroi species complex: Detection of additionally phylogenetically distinct species. Mycoscience 2000, 41, 61-78. [CrossRef]

16. Geiser, D.M.; Ivey, M.L.; Hakiza, G.; Juba, J.H.; Miller, S.A. Gibberella xylarioides (anamorph: Fusarium xylarioides), a causative agent of coffee wilt disease in Africa, is a previously unrecognized member of the G. fujikuroi species complex. Mycologia 2005, 97, 191-201. [CrossRef]

17. Moroti, R.V.; Gheorghita, V.; Al-Hatmi, A.M.S.; De Hoog, G.S.; Meis, J.F.; Netea, M.G. Fusarium ramigenum, a novel human opportunist in a patient with common variable immunodeficiency and cellular immune defects: Case report. BMC Infect. Dis. 2016, 16, 79. [CrossRef]

18. Sauer, J.D. Historical Geography of Crop Plants: A Select Roster; CRC Press: Boca Raton, FL, USA, 1993.

19. Bresler, G.; Brizzio, S.B.; Vaamonde, G. Mycotoxin-producing potential of fungi isolated from amaranth seeds in Argentina. Internat. J. Food Microbiol. 1995, 25, 101-108. [CrossRef]

20. Blodgett, J.T.; Swart, W.J.; Chen, W. First report of Alternaria tenuissima as leaf pathogen of Amaranthus hybridus. Plant Dis. 1999, 83, 878. [CrossRef] [PubMed]

21. Chen, W.Q.; Swart, W.J. Fusarium oxysporum and F. sambucinum associated with root rot of Amaranthus hybridus in South Africa. Plant Dis. 2000, 84, 101. [CrossRef]

22. Vermeulen, M.; Marais, G.J.; Louw, S.; van der, M.; Weeks, W.; Swart, W.J.; Gryzenhout, M. Fungi associated with disease and weevil damage of Amaranthus cruentus in South Africa. Afr. Entomol. 2017, 26, 174-188. [CrossRef]

23. Blodgett, J.T.; Swart, W.J.; Louw, S.; van der, M. Identification of fungi and fungal pathogens associated with Hypolixus haerens and decayed and cankered stem of Amaranthus hybridus. Plant Dis. 2004, 88, 333-337. [CrossRef]

24. Möller, E.M.; Bahnweg, G.; Sandermann, H.; Geiger, H.H. A simple and efficient protocol for isolation of high molecular weight DNA from filamentous fungi, fruit bodies and infected plant tissues. Nucleic Acids Res. 1992, 20, 6115-6116. [CrossRef]

25. O'Donnell, K.; Sutton, D.A.; Fothergill, A.; McCarthy, D.; Rinaldi, M.G.; Brandt, M.E.; Zhang, N.; Geiser, D.M. Molecular phylogenetic diversity, multilocus haplotype nomenclature, and in vitro antifungal resistance within the Fusarium solani species complex. J. Clin. Microbiol. 2008, 46, 2477-2490. [CrossRef]

26. O'Donnell, K.; Cigelnik, E. Two divergent intragenomic rDNA ITS2 types within a monophyletic lineage of the fungus Fusarium are nonorthologous. Mol. Phylogenetics Evol. 1997, 7, 103-116. [CrossRef]

27. Liu, Y.J.; Whelen, S.; Hall, B.D. Phylogenetic relationships among Ascomycetes: Evidence from an RNA polymerase II subunit. Mol. Biol. Evol. 1999, 16, 1799-1808. [CrossRef] [PubMed]

28. Sung, G.-H.; Sung, J.-M.; Hywel-Jones, N.L.; Spatafora, J.W. A multi-gene phylogeny of Clavicipitaceae (Ascomycota, Fungi): Identification of localized incongruence using a combinational bootstrap approach. Mol. Phylogenetics Evol. 2007, 44, 1204-1223. [CrossRef]

29. Katoh, K.; Misawa, K.; Kuma, K.; Miyata, T. MAFFT: A novel method for rapid multiple sequence alignment based on Fourier transform. Nucleic Acids Res. 2002, 30, 3059-3066. [CrossRef] [PubMed] 
30. Katoh, K.; Kuma, K.; Toh, H.; Miyata, T. MAFFT version 5: Improvement in accuracy of multiple sequence alignment. Nucleic Acids Res. 2005, 33, 511-518. [CrossRef] [PubMed]

31. Katoh, K.; Standley, D.M. MAFFT multiple sequence alignment software version 7: Improvements in performance and usability. Mol. Biol. Evol. 2013, 30, 772-780. [CrossRef]

32. Katoh, K.; Toh, H. Recent developments in the MAFFT multiple sequence alignment program. Brief. Bioinform. 2008, 9, 286-298. [CrossRef]

33. O'Donnell, K.; Kistler, H.C.; Cigelnik, E.; Ploetz, R.C. Multiple evolutionary origins of the fungus causing Panama disease of banana: Concordant evidence from nuclear and mitochondrial gene genealogies. Proc. Natl. Acad. Sci. USA 1998, 95, 2044-2049. [CrossRef] [PubMed]

34. Felsenstein, J. Confidence limits on phylogenies: An approach using the bootstrap. Evolution 1985, 39, 783-791. [CrossRef]

35. Posada, D. jModelTest: Phylogenetic Model Averaging. Mol. Biol. Evol. 2008, 25, 1253. [CrossRef] [PubMed]

36. Tamura, K.; Nei, M. Estimation of the number of nucleotide substitutions in the control region of mitochondrial DNA in humans and chimpanzees. Mol. Biol. Evol. 1993, 10, 512-526. [PubMed]

37. Tavare, S. Some probabilistic and statistical problems in the analysis of DNA sequences. In Some Mathematical Questions in Biology-DNA Sequence Analysis; Miura, R.M., Ed.; American Mathematical Society: Providence, RI, USA, 1986 ; pp. 57-86.

38. Nirenberg, H.I. Untersuchungen über die morphologische und biologische Differenzierung in der Fusarium-sektion Liseola. Mitt. Biol. Für Land-Und Forstwirtschaft Berl.-Dahl. 1976, 169, 1-117.

39. Nelson, P.E.; Toussoun, T.A.; Marasas, W.F.O. Fusarium Species: An. Illustrated Manual for Identification; Pennsylvania State University Press: State College, PA, USA, 1983.

40. Jacobs, A.; Van Wyk, P.S.; Marasas, W.F.; Wingfield, B.D.; Wingfield, M.J.; Coutinho, T.A. Fusarium ananatum sp. nov. in the Gibberella fujikuroi species complex from pineapples with fruit rot in South Africa. Fungal Biol. 2010, 114, 515-527. [CrossRef]

41. De Mendiburu, F. Agricolae: Statistical Procedures for Agricultural Research. R Package Version 1.3-2. Available online: https:/ /CRAN.R-project.org/package=agricolae2020 (accessed on 23 March 2021).

42. Rayner, R.W. A Mycological Colour Chart; CMI and British Mycological Society: London, UK, 1970.

43. Modi, A.T. Growth temperature and plant age influence on nutritional quality of Amaranthus leaves and seed germination capacity. Water SA 2007, 33, 369-376. [CrossRef]

44. Sakalidis, M.L.; Ray, J.D.; Lanoiselet, V.; Hardy, G.E.S.; Burgess, T.I. Pathogenic Botryosphaeriaceae associated with Mangifera indica in the Kimberley Region of Western Australia. Eur. J. Plant Pathol. 2011, 130, 379-391. [CrossRef]

45. R Core Team. R: A Language and Environment for Statistical Computing; R Foundation for Statistical Computing: Vienna, Austria, 2020; Available online: https: / / www.R-project.org/ (accessed on 3 March 2021).

46. RStudio Team. RStudio: Integrated Development Environment for $R$ (Version 1.2.5042) [Computer Software]; RS-Team-Inc.: Boston, MA, USA, 2020.

47. Wickham, H.; Averick, M.; Bryan, J.; Chang, W.; D’Agostino McGowan, L.; François, R.; Grolemund, G.A.; Henry, L.; Hester, J.; Kuhn, M.; et al. Welcome to the tidyverse. J. Open Source Softw. 2019, 4, 1686. [CrossRef]

48. Marasas, W.F.O.; Rabie, C.J.; Lübben, A.; Nelson, P.E.; Toussoun, T.A.; van Wijk, P.S. Fusarium napiforme, a new species from millet and sorghum in southern Africa. Mycologia 1978, 79, 910-914. [CrossRef]

49. Nirenberg, H.I.; O'Donnell, K. New Fusarium species and combinations within the Gibberella fujikuroi species complex. Mycologia 1998, 90, 434-458. [CrossRef]

50. Van Hove, F.; Waalwijk, C.; Logrieco, A.; Munaut, F.; Moretti, A. Gibberella musae (Fusarium musae) sp. nov., a recently discovered species from banana is sister to F. verticillioides. Mycologia 2011, 103, 570-585. [CrossRef] [PubMed]

51. Gams, W. Cephalosporium-Artige Schimmelpilze (Hyphomycetes); Fischer: Stuttgart, Germany, 1971.

52. Aoki, T.; O'Donnell, K.; Ichikawa, K. Fusarium fractiflexum sp. nov. and two other species within the Gibberella fujikuroi species complex recently discovered in Japan that form aerial conidia in false heads. Mycoscience 2001, 42, 461-478. [CrossRef]

53. Yilmaz, N.; Sandoval-Denis, M.; Lombard, L.; Visagie, C.M.; Wingfield, B.D.; Crous, P.W. Redefining species limits in the Fusarium fujikuroi species complex. Pers. Mol. Phylogeny Evol. Fungi 2021, 46, 129-162.

54. Britz, H.; Steenkamp, E.T.; Coutinho, T.A.; Wingfield, B.D.; Marasas, W.F.O.; Wingfield, M.J. Two new species of Fusarium section Liseola associated with mango malformation. Mycologia 2002, 94, 722-730. [CrossRef] [PubMed]

55. Otero-Colina, G.; Rodríguez-Alvarado, G.; Fernández-Pavía, S.; Maymon, M.; Ploetz, R.C.; Aoki, T.; O’Donnell, K.; Freeman, S. Identification and characterization of a novel etiological agent of mango malformation disease in Mexico. Phytopathology 2010, 100, 1176-1184. [CrossRef] [PubMed]

56. Lima, C.S.; Pfenning, L.H.; Costa, S.S.; Abreu, L.M.; Leslie, J.F. Fusarium tupiense sp. nov., a member of the Gibberella fujikuroi complex that causes mango malformation in Brazil. Mycologia 2012, 104, 1408-1419. [CrossRef]

57. Gerlach, W.; Nirenberg, H. Mitteilungen aus der Bioloischen Bundesansalt fur Land- und Forstwirschaft. In The Genus Fusarium: A Pictorial Atlas; Parey: Berlin, Germany, 1982; Volume 209, pp. 1-406.

58. Kerry O’Donnell, K.; Humber, R.A.; Geiser, D.M.; Kang, S.; Park, B.; Robert, V.A.R.G.; Crous, P.W.; Johnston, P.; Aoki, T.; Rooney, A.P.; et al. Phylogenetic diversity of insecticolous fusaria inferred from multilocus DNA sequence data and their molecular identification via FUSARIUM-ID and Fusarium MLST. Mycologia 2012, 104, 427-445. [CrossRef] 